\title{
Seismic Evaluation of Shallow-Depth Structure, Faulting, and Groundwater Variations Across the Dos Palmas Preserve, Riverside County, California
}

Open-File Report 2019-1130

U.S. Department of the Interior U.S. Geological Survey 
Cover. Photo of the U.S. Geological Survey seismic crew acquiring seismic data at Dos Palmas Preserve, California. 


\section{Seismic Evaluation of Shallow-Depth Structure, Faulting, and Groundwater Variations Across the Dos Palmas Preserve, Riverside County, California}

By Rufus D. Catchings, Mark R. Goldman, Joanne H. Chan, Robert R. Sickler, Michael J. Rymer, and Coyn J. Criley

Open-File Report 2019-1130 


\title{
U.S. Department of the Interior \\ DAVID BERNHARDT, Secretary
}

\author{
U.S. Geological Survey \\ James F. Reilly II, Director
}

U.S. Geological Survey, Reston, Virginia: 2020

For more information on the USGS - the Federal source for science about the Earth, its natural and living resources, natural hazards, and the environment-visit https://www.usgs.gov or call 1-888-ASK-USGS.

For an overview of USGS information products, including maps, imagery, and publications, visit https://store.usgs.gov/.

Any use of trade, firm, or product names is for descriptive purposes only and does not imply endorsement by the U.S. Government.

Although this information product, for the most part, is in the public domain, it also may contain copyrighted materials as noted in the text. Permission to reproduce copyrighted items must be secured from the copyright owner.

Suggested citation:

Catchings, R.D., Goldman, M.R., Chan, J.H., Sickler, R.R., Rymer, M.J., and Criley, C.J., 2020, Seismic evaluation of shallow-depth structure, faulting, and groundwater variations across the Dos Palmas Preserve, Riverside County, California: U.S. Geological Survey Open-File Report 2019-1130, 21 p., https://doi.org/10.3133/ofr20191130.

Associated data for this publication:

Chan, J.H., Catchings, R.D., Goldman, M.R., Criley, C.J., and Sickler, R.R., 2018, 2015 high resolution seismic acquisition at Dos Palmas Preserve, Mecca, California: U.S. Geological Survey data release, https://doi.org/10.5066/ P9W0J5EH.

ISSN 2331-1258 (online) 


\section{Acknowledgments}

We thank the rangers of Dos Palmas Preserve and the Bureau of Land Management (BLM) for providing access. We thank Matthew Landon and Belle Philibosian of the U.S. Geological Survey (USGS) for providing critical reviews and Regan Austin for editing. We thank Keith Galvin, Ryan Fay, Caitriona Keogh, Adrian McEvilly, and Seth Shuler, who were USGS Volunteers For Science, for assistance in the field. Funding was provided by the BLM, the USGS Earthquake Hazards Program, and the USGS Earthquake Science Center. 


\section{Contents}

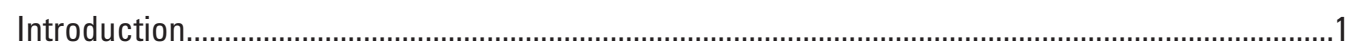

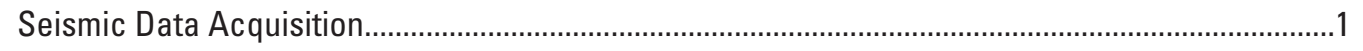

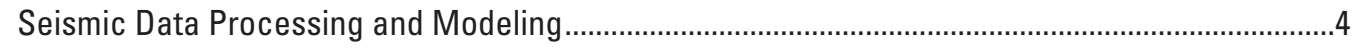

Refraction Tomography Modeling .................................................................................

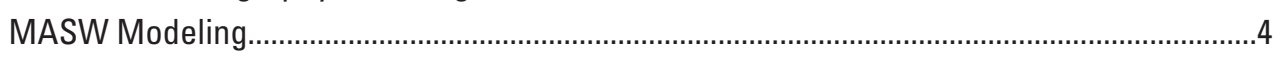

$V_{\mathrm{p}} / V_{\mathrm{S}}$ Ratio and Poisson's Ratio Development ....................................................................

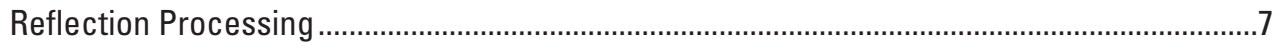

Seismic Models and Images........................................................................................................

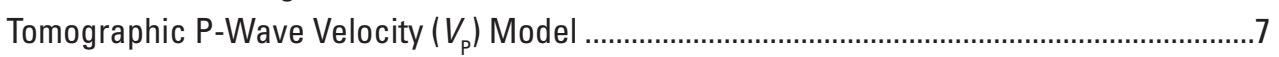

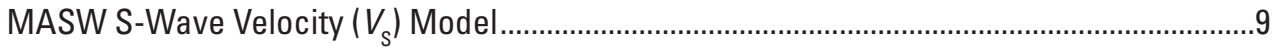

$V_{\mathrm{p}} / V_{\mathrm{S}}$ Ratio Models................................................................................................

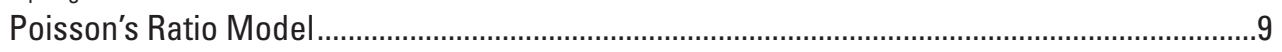

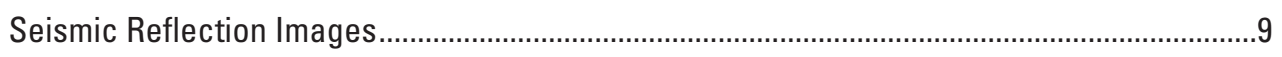

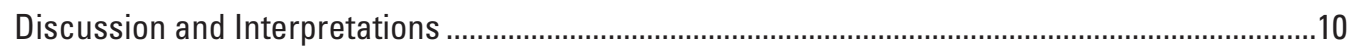

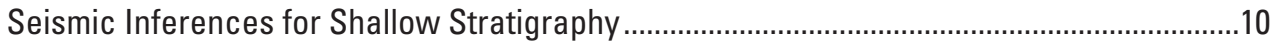

Seismic Inferences for Groundwater ..............................................................................

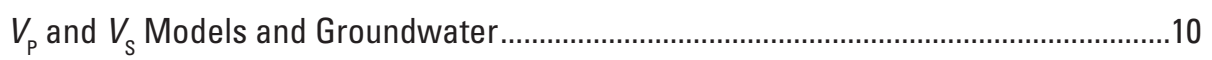

Reflection Images and Groundwater .......................................................................13

$V_{\mathrm{p}} / V_{\mathrm{S}}$ Ratios and Groundwater..........................................................................13

Poisson's Ratio and Groundwater.................................................................................13

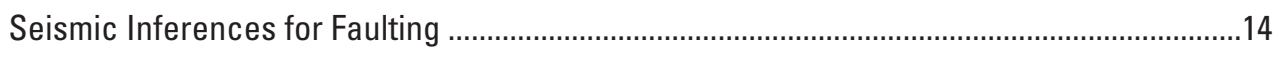

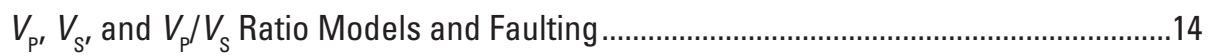

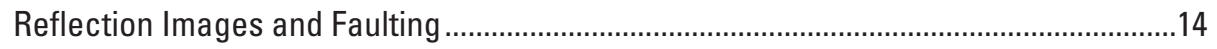

Combined Images and Faulting Along the Seismic Profile .............................................14

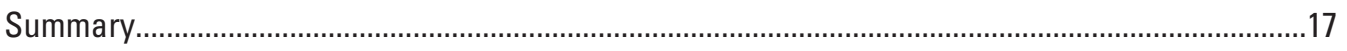

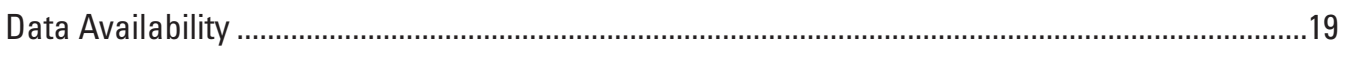

References Cited................................................................................................................... 


\section{Figures}

1. Satellite images showing vicinity of the study area, northeast of the Salton Sea

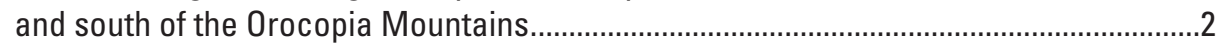

2. Satellite images of the study area showing surface geology ..............................................

3. Close-up satellite image of Dos Palmas Preserve ..............................................................

4. Satellite image showing northern part of Dos Palmas Preserve ......................................

5. Plots of tomographic $V_{\mathrm{p}}$ model along the Dos Palmas Preserve seismic profile...............5

6. Plots of MASW-based $V_{s}$ model along the Dos Palmas Preserve seismic profile............5

7. Plots of $V_{\mathrm{p}} / V_{\mathrm{s}}$ ratio model along the Dos Palmas Preserve seismic profile.......................6

8. Plots of Poisson's ratio model along the Dos Palmas Preserve seismic profile ...............7

9. Plots of topography and seismic reflection along the Dos Palmas Preserve seismic profile.

10. Example line drawings from two areas along the seismic reflection image of the Dos Palmas Preserve seismic profile.

11. Comparison plots of topography, seismic reflection, and $V_{\mathrm{p}}$ along the Dos Palmas Preserve seismic profile..

12. Comparison plots of topography, seismic reflection, and interpretive stratigraphy along the Dos Palmas Preserve seismic profile.

13. Comparison plots of topography, seismic reflection, and $V_{s}$ along the Dos Palmas Preserve seismic profile...

14. Comparison plots of topography, seismic reflection, and $V_{\mathrm{p}} / V_{\mathrm{S}}$ ratio along the Dos Palmas Preserve seismic profile.

15. Comparison plots of topography, seismic reflection, and Poisson's ratio along the Dos Palmas Preserve seismic profile.

\section{Conversion Factors}

International System of Units to U.S. customary units

\begin{tabular}{|c|c|c|}
\hline Multiply & By & To obtain \\
\hline \multicolumn{3}{|c|}{ Length } \\
\hline meter (m) & 3.281 & foot $(\mathrm{ft})$ \\
\hline kilometer $(\mathrm{km})$ & 0.6214 & mile (mi) \\
\hline \multicolumn{3}{|c|}{ Flow rate } \\
\hline meter per second $(\mathrm{m} / \mathrm{s})$ & 3.281 & foot per second $(\mathrm{ft} / \mathrm{s})$ \\
\hline \multicolumn{3}{|c|}{ Mass } \\
\hline kilogram (kg) & 2.205 & pound avoirdupois (lb) \\
\hline \multicolumn{3}{|c|}{ U.S. customary units to International System of Units } \\
\hline Multiply & By & To obtain \\
\hline \multicolumn{3}{|c|}{ Length } \\
\hline mile (mi) & 1.609 & kilometer $(\mathrm{km})$ \\
\hline \multicolumn{3}{|c|}{ Mass } \\
\hline pound, avoirdupois (lb) & 0.4536 & kilogram (kg) \\
\hline
\end{tabular}




\section{Abbreviations}

$\begin{array}{ll}\text { 1D } & \text { one dimensional } \\ \text { 2D } & \text { two dimensional } \\ \text { AGC } & \text { automatic gain control } \\ \text { BLM } & \text { U.S. Department of the Interior, Bureau of Land Management } \\ \text { CMPCC } & \text { common midpoint cross correlation } \\ \text { Hz } & \text { hertz } \\ \text { MASW } & \text { multichannel analysis of surface waves using Rayleigh waves } \\ \text { USGS } & \text { U.S. Geological Survey } \\ V_{P} & \text { P-wave or compressional-wave velocity } \\ V_{S} & \text { S-wave or shear-wave velocity }\end{array}$




\title{
Seismic Evaluation of Shallow-Depth Structure, Faulting, and Groundwater Variations Across the Dos Palmas Preserve, Riverside County, California
}

\author{
By Rufus D. Catchings, Mark R. Goldman, Joanne H. Chan, Robert R. Sickler, Michael J. Rymer, and \\ Coyn J. Criley
}

\section{Introduction}

Dos Palmas Preserve is a Colorado Desert oasis and wetland (1,400 acres; 566 hectares) in Riverside County, California, located near the base of the Orocopia Mountains and northeast of the Salton Sea (fig. $1 A, B$ ). The original source of water for the oasis was artesian springs that developed at the base of the Orocopia Mountains, but more abundant water supplies were later provided to Dos Palmas Preserve when the Coachella Canal (fig. $2 A, B$ ) was built and water seeped from unlined parts of the canal (Hibbs and others, 2011). As a result of this abundant water supply in a desert setting (figs. 3, 4), Dos Palmas Preserve, managed by the Bureau of Land Management, is now a wildlife preserve that became home to multiple plants, fowl, insects, rodents, reptiles, and bats, including some endangered and threatened species. More recently, sections of the Coachella Canal have been lined, resulting in a reduction of water seepage and threatening the sustainability of parts of Dos Palmas Preserve (Hibbs and others, 2011). Faults usually act as barriers to groundwater flow (Wallace and Morris, 1986; Bredehoeft and others, 1992) and Dos Palmas Preserve is only a few kilometers from the active trace of the San Andreas Fault, where splays of the fault trend through the area. Additionally, numerous closely spaced faults that have been mapped at the surface northwest of Dos Palmas Preserve are believed to extend southward into the Dos Palmas Preserve, where they are covered by alluvium (Babcock, 1974). Thus, evaluation of the subsurface lithology and structure is needed to determine how the current allocation of water from the Coachella Canal affects various parts of Dos Palmas Preserve.

To better understand the distribution of the shallow lithology, faulting, and groundwater in Dos Palmas Preserve, the U.S. Geological Survey (USGS), in collaboration with the Bureau of Land Management, conducted a seismic survey across the northern part of Dos Palmas Preserve. The seismic survey was designed to "map" the upper part of the aquifer system and to more precisely locate faults (fig. $2 A, B$ ) that may affect groundwater flow in Dos Palmas Preserve. In this report, we present seismic velocity and reflection images of the shallow subsurface and relate those images to interpretative structures and stratigraphy that may affect groundwater at Dos Palmas Preserve.

\section{Seismic Data Acquisition}

In March 2015, we acquired high-resolution P-wave seismic data along a 2,800-m-long, northeast-southwest-trending profile across the northern part of the Dos Palmas Preserve (figs. 2-4). The data were recorded on a 240-channel moving array of GeometricsRX-60® seismographs, connected to $40-\mathrm{Hz}$ vertical-component geophones via refraction cables. Because three of the channels were inactive, we recorded each shot with a total of 237 active channels. The geophones were spaced at 3-m intervals along the seismic profile, resulting in 933 recording sites, 925 of which had co-located (1-m perpendicular offset) seismic shot points. At each shot point, the seismic energy was generated by one of two sources. One seismic source consisted of a 4-kg hammer that was used to vertically strike an aluminum plate on the ground surface. The second seismic source was generated by a Betsy Seisgun ${ }^{\circledR}$ that fired 400-grain, black-powder blanks into the subsurface at about $0.3 \mathrm{~m}$ depth. The seisgun "shot" was used at every 30th shot point, and the hammer "shot" was used at every shot point, except those where the seisgun was used. The more powerful seisgun generated better propagation, and it allowed us to use reciprocal first-break arrival times where arrivals from the hammer shots were less clear.

We acquired the data in a manner such that there were active geophones on both sides of each shot point, which allowed for reversing ray paths along the seismic profile. For the initial deployment, 240 channels (geophones), spaced at 3-m intervals, were deployed along the northeasternmost $720 \mathrm{~m}$ of the seismic profile (fig. 4). Seismic sources were generated along the first 180 shot points and recorded by the stationary array. The northeasternmost 120 channels of the array were then moved to the southwestern part of the active recording array, leaving 60 channels $(180 \mathrm{~m})$ northeast of that shot point and 180 channels $(540 \mathrm{~m})$ southwest of that shot point. Seismic sources were then generated along the next 120 shot points of the array. This process was repeated until the entire 2800-m-long seismic profile was acquired. These data are available from Chan and others (2018).

Each seismic source (shot) at the 925 shot points was recorded by 237 geophones, allowing for high redundancy. Because the data were recorded with vertical-component geophones, the data consist dominantly of compressional (P) 
$\boldsymbol{A}$

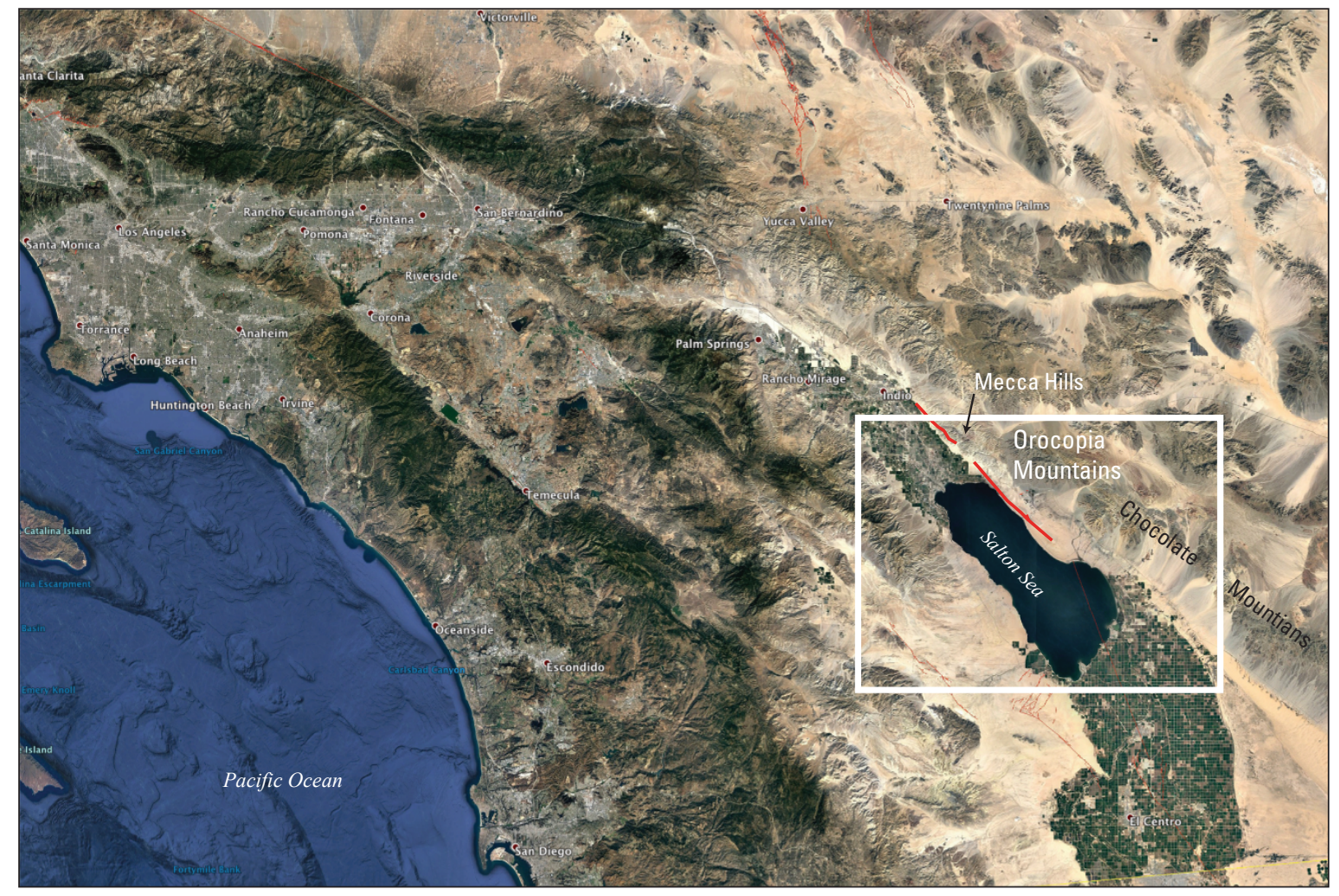

Data LDEO-Columbia, NSF, NOAA, 2018, Google. Image Landsat/Copernicus, 2018, INEGI.

200 KILOMETERS

B

Figure 1. Satellite images showing vicinity of the study area, northeast of the Salton Sea and south of the Orocopia Mountains. Bold red lines show location of the San Andreas Fault; thin red lines show historical fault ruptures in our general study area mapped by Babcock (1974). A, Image of southwestern California and northwestern Mexico. Large white rectangle shows location of part $B$. $B$, Close-up view of the study area. White rectangle encloses Dos Palmas Preserve; magenta line shows location of the Dos Palmas Preserve seismic profile.

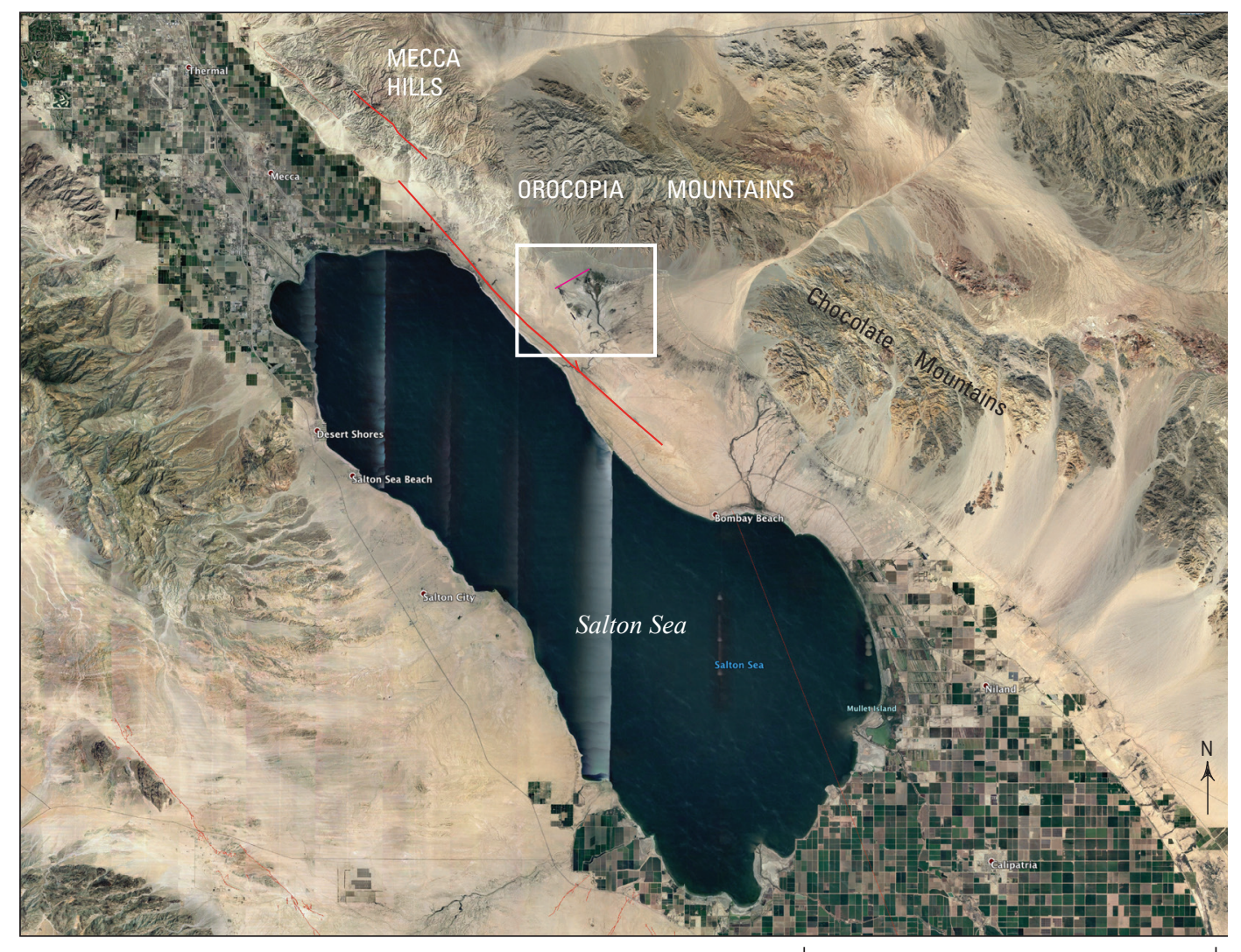


$\boldsymbol{A}$

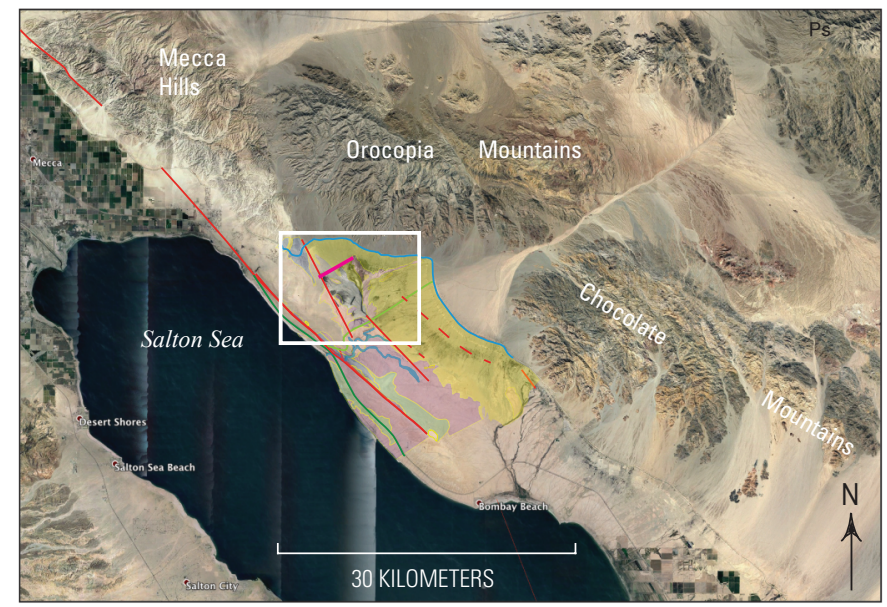

B

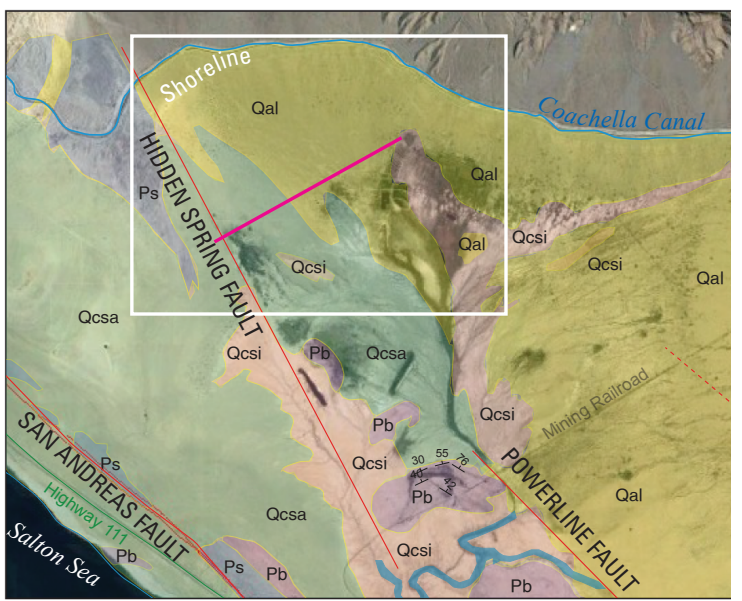

Base map data from Google, 2018

\section{EXPLANATION}

Sedimentary rocks

$\begin{array}{lll}\text { Holocene } & \text { Qal } & \text { Quaternary alluvium } \\ \text { Pleistocene } & \text { Qcsa } & \text { Lake Cahuilla sands } \\ \text { Early Holocene } & & \\ & \text { Qcsi } & \text { Lake Cahuilla silts } \\ \text { Pleistocene } & \text { Pb } & \text { Borrego Formation }\end{array}$

Plio-Pleistocene Ps Shavers Well Formation

From Babcock (1974)
Figure 2. Satellite images of the study area showing surface geology mapped by Babcock (1974). Red lines show historical fault ruptures mapped (solid) and inferred (dashed) by Babcock (1974). Magenta line shows location of the Dos Palmas Preserve seismic profile. A, Image of the study area from figure $1 B$ with surface geology superimposed. White rectangle encloses Dos Palmas Preserve and shows location of part $B$. $B$, Close-up view of Dos Palmas Preserve with surface geology superimposed. Descriptions of geological units shown in part $A$.

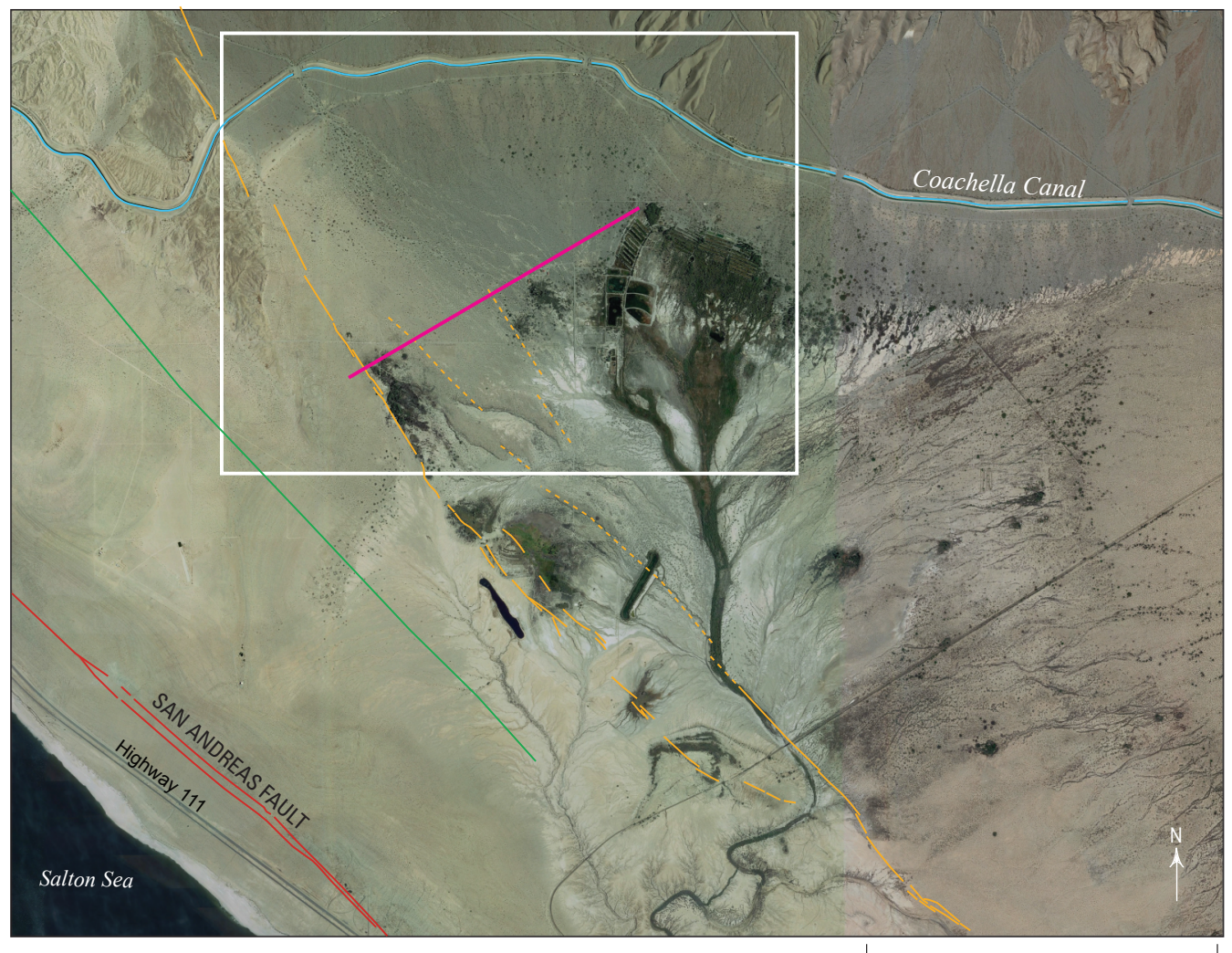

2018 GOOGLE EARTH
Figure 3. Close-up satellite image of Dos Palmas Preserve. Magenta line shows location of the Dos Palmas Preserve seismic profile; red lines show historical surface rupture of the San Andreas Fault. Solid green line shows trace of the Mecca Hills fault zone, and solid yellow lines show traces of the Hidden Spring fault zone (U.S. Geological Survey and California Geological Survey, 2006). Dashed yellow lines show our interpreted fault traces based on vegetation lineaments and stream channel deflection. White rectangle shows location of figure 4. 


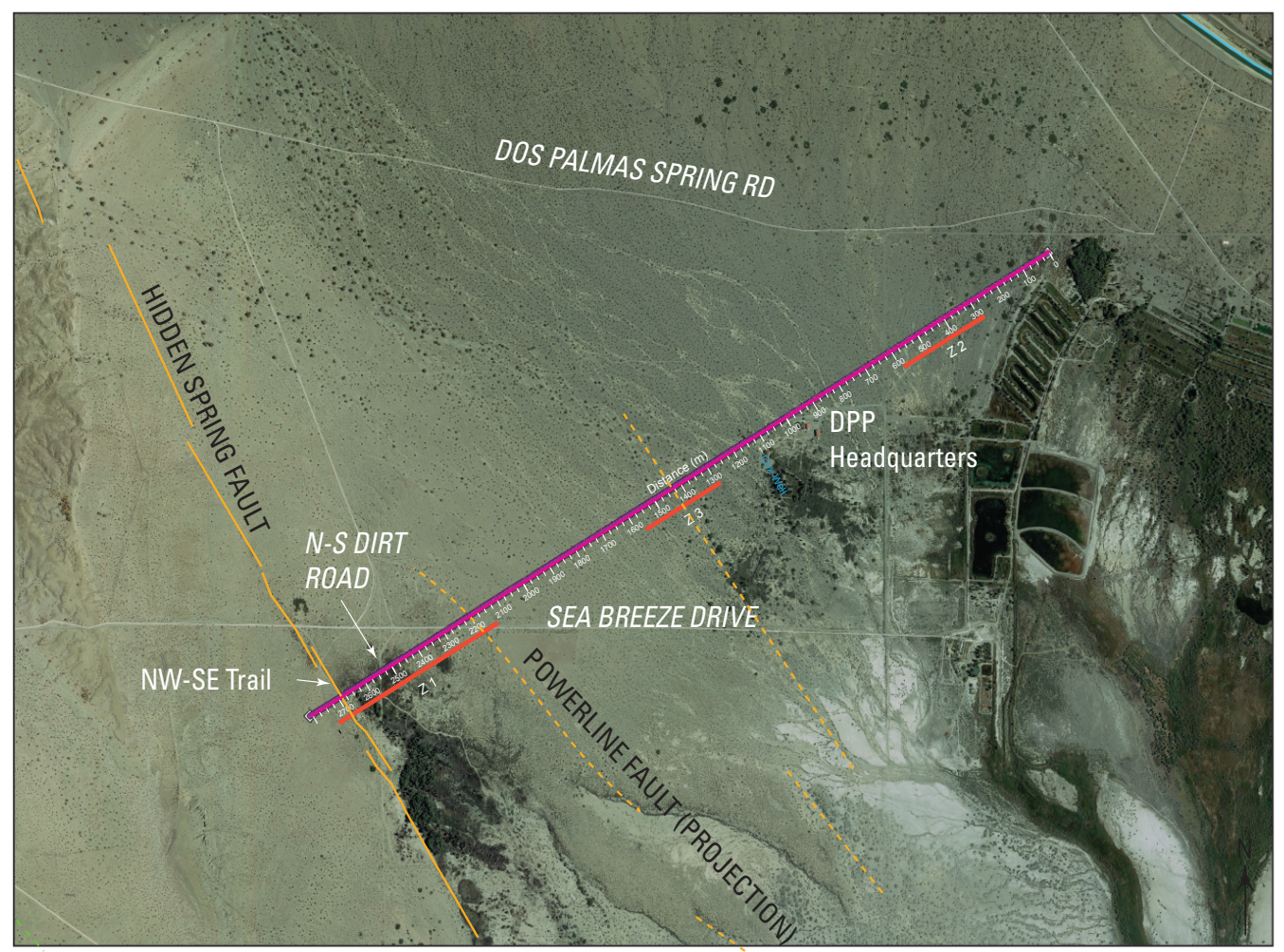

Figure 4. Satellite image showing northern part of Dos Palmas Preserve. Magenta line shows location of the Dos Palmas Preserve seismic profile; red lines (labeled $\mathrm{Z1}, \mathrm{Z2}$, and Z3) show locations of interpreted zones of intense faulting discussed in the text. Solid yellow lines show traces of the Hidden Spring fault from U.S. Geological Survey and California Geological Survey (2006). Dashed yellow lines show our interpreted fault traces based on vegetation lineaments and stream channel deflections. Numerical scale shows distance along the seismic profile, starting from the northeast. Surface flow channels and denser vegetation in the northwestern part of the image are evidence of water flowing from Coachella Canal to Dos Palmas Preserve.

body waves and their associated surface (Rayleigh) waves. Topography varied by approximately $16.7 \mathrm{~m}$, as determined by a high-precision global positioning system, over the 2,800-m-long seismic profile.

\section{Seismic Data Processing and Modeling}

The data acquisition geometry allowed us to develop multiple types of seismic models and images, including a high-resolution (1) refraction tomography P-wave velocity $\left(V_{\mathrm{P}}\right)$ model, (2) Multichannel Analysis of Surface Waves (MASW) S-wave velocity $\left(V_{\mathrm{S}}\right.$ ) model, (3) $V_{\mathrm{P}} / V_{\mathrm{S}}$ ratio model, and (4) Poisson's ratio model, and (5) P-wave reflection image. We use each of the models and images to better constrain our overall interpretation of the shallow subsurface in the Dos Palmas area. We briefly describe the various seismic methods used.

\section{Refraction Tomography Modeling}

Using the algorithm of Hole (1992), we developed a 2D $V_{\mathrm{P}}$ model (fig. 5) from first-arrival refractions measured on $\mathrm{P}$-wave shot gathers. The algorithm uses finite differences (solving the eikonal equation) to compute first-arrival travel times from the source to the receiver in a starting velocity model. It then uses back-projection of the data misfits to update the model. This process is repeated in iterative steps until a satisfactory fit among observed and calculated first arrivals is obtained. We inverted the $2 \mathrm{D} V_{\mathrm{p}}$ model using a $3-\mathrm{m}$ by $3-\mathrm{m}$ grid and as many as 219,225 first arrivals, which allowed for a high degree of redundancy and high resolution within the model. Our starting models were developed from $1 \mathrm{D}$ analysis of shot gathers along the seismic profile. We used multiple starting models, but all final models were similar, with less than about 2 percent variation among the models where best resolved.

\section{MASW Modeling}

We developed a $V_{\mathrm{S}}$ model (fig. 6) from the Rayleigh waves recorded on our P-wave shot gathers using a variation of the MASW technique originally developed by Park and others (1999). Specifically, we used the MASW method (Geometrics ${ }^{\circledR} 2$ D SeisImager ${ }^{\mathrm{TM}}$ software) of Hayashi and Suzuki (2004) and Hayashi (2008) to invert the Rayleigh waves (recorded on the P-wave dataset) and develop a 2-dimensional (2D) $V_{\mathrm{S}}$ model, referred to in this report as the MASW $V_{\mathrm{S}}$ velocity model. MASW modeling uses surfacewave dispersion curves developed from common midpoint stacks, which are derived from multiple shotgathers, to infer $V_{\mathrm{S}}$. We used a total of 93 shot gathers to construct $366 \mathrm{com}-$ mon midpoint cross-correlation (CMPCC) gathers, whereby a gather was constructed for every 10 shots $(30 \mathrm{~m})$ along the seismic profile, and the $2 \mathrm{D} V_{\mathrm{S}}$ model was derived from a total of 300 dispersion curves. 


\section{Dos Palmas $V_{\mathrm{p}}$ Model}

$\boldsymbol{A}$

Fault zone

Fault zone 3

Fault zone 1

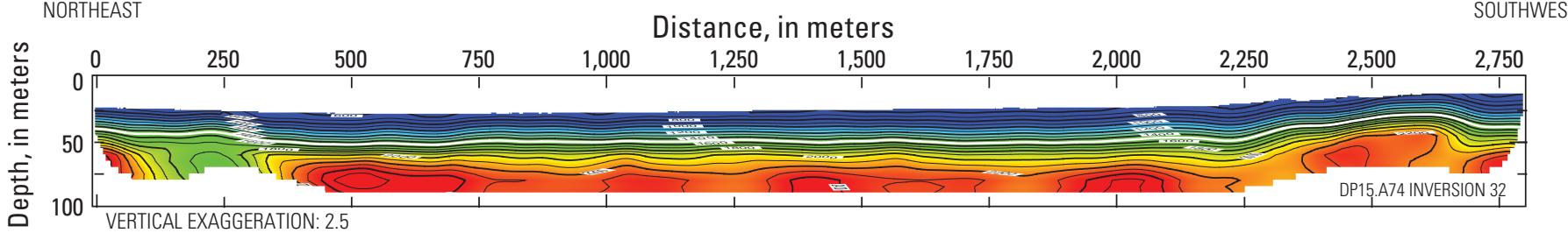

SOUTHWEST

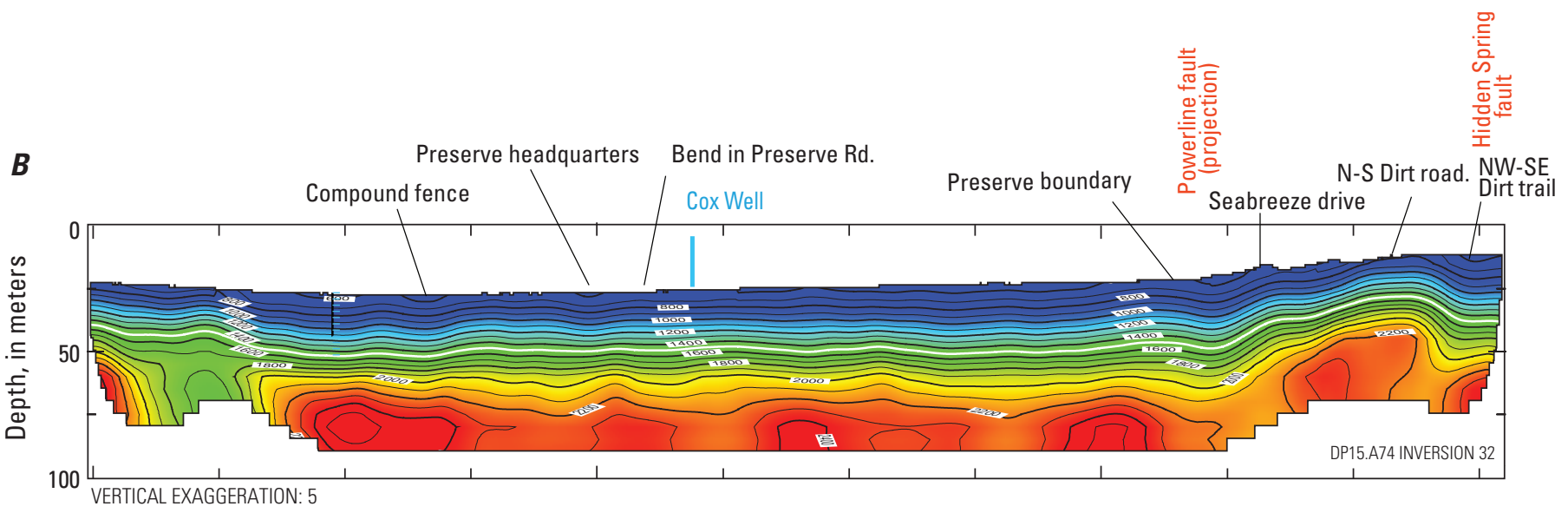

EXPLANATION

$V_{\mathrm{p}}(\mathrm{m} / \mathrm{s})$
800
1,200
2,400
1,600
2,000

Figure 5. Plots of tomographic P-wave velocity $\left(V_{\mathrm{p}}\right)$ model along the Dos Palmas Preserve seismic profile, in meters per second ( $\mathrm{m} / \mathrm{s}$ ). Depth (left axis) is relative to a datum about $10 \mathrm{~m}$ above the topographically highest point along the seismic profile; land surface is approximately at top of colored contours. $A$, Model plotted with 2.5x vertical exaggeration (VE). B, Model plotted with $5 x$ vertical exaggeration. Landmarks along the seismic profile are shown along top axis.

A

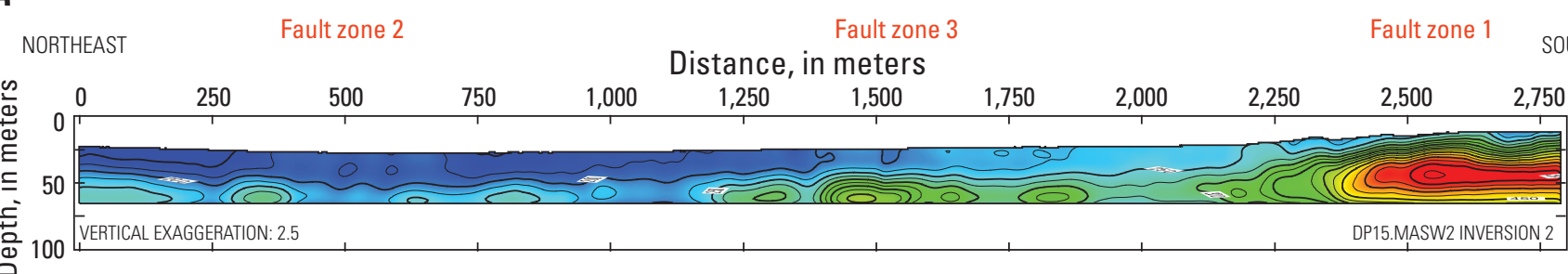

\section{Dos Palmas $V_{s}$ Model}

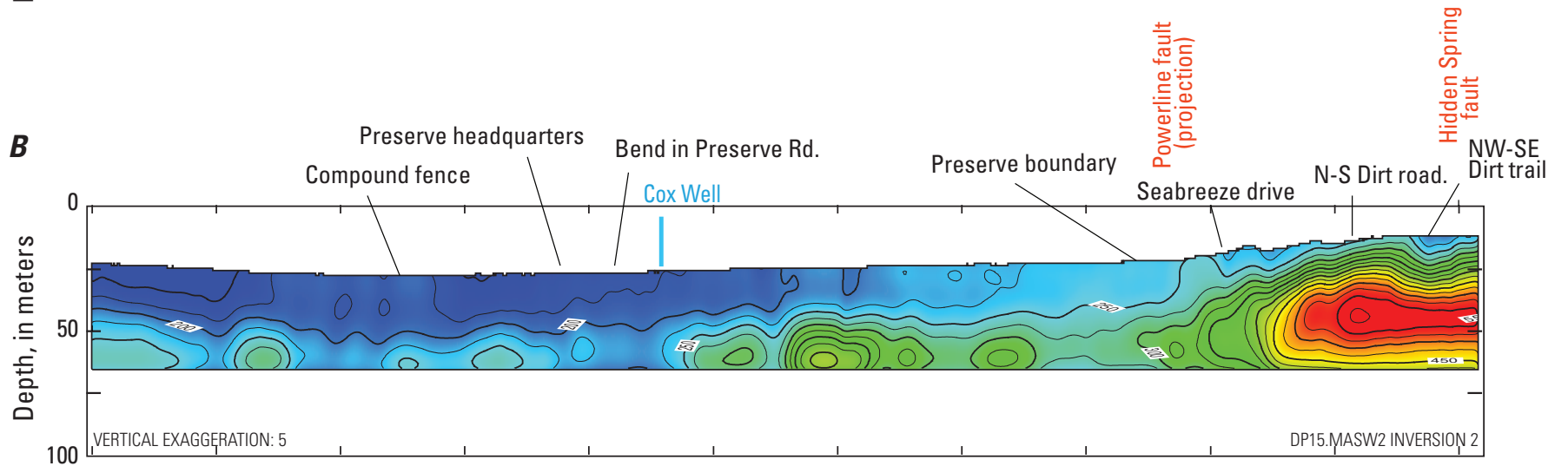

EXPLANATION

$\boldsymbol{V}_{\mathrm{s}}(\mathbf{m} / \mathbf{s})$
150
250
350
450
550

Figure 6. Plots of multichannel analysis of surface waves (MASW)-based S-wave velocity $\left(V_{s}\right)$ model along the Dos Palmas Preserve seismic profile, in meters per second (m/s). Depth (left axis) is relative to a datum about $10 \mathrm{~m}$ above the topographically highest point along the seismic profile; land surface is approximately at top of colored contours. $A$, Model plotted with $2.5 \mathrm{x}$ vertical exaggeration (VE). $B$, Model plotted with $5 x$ vertical exaggeration. Landmarks along the seismic profile are shown 


\section{$V_{\mathrm{p}} / V_{\mathrm{s}}$ Ratio and Poisson's Ratio Development}

Using the method described by Catchings and others (2014), we developed a model of $V_{\mathrm{P}} / V_{\mathrm{S}}$ ratios along the seismic profile by dividing $V_{\mathrm{P}}$ (from tomography) by $V_{\mathrm{S}}$ (from MASW) at each node of the velocity models where they overlapped (fig. 7). We parameterized the $V_{\mathrm{P}}$ and $V_{\mathrm{S}}$ models with the same grid spacing $(3 \times 3 \mathrm{~m})$ so that the $V_{\mathrm{P}} / V_{\mathrm{S}}$ ratios could be calculated at each node. However, because the maximum depth of imaging was shallower for the MASW $V_{\mathrm{S}}$ model than the tomographic $V_{\mathrm{P}}$ model, we could develop the $V_{\mathrm{P}} / V_{\mathrm{S}}$ ratio model only to the maximum depth of the $V_{\mathrm{S}}$ model. In addition, because of the lower resolution of the $V_{\mathrm{S}}$ model (see above), the $V_{\mathrm{p}} / V_{\mathrm{S}}$ ratio model is necessarily averaged over longer lateral distances than the $V_{\mathrm{P}}$ model. Thus, the $V_{\mathrm{P}} / V_{\mathrm{S}}$ model spreads anomalies over greater lateral distances.
In a manner similar to that for $V_{\mathrm{p}} / V_{\mathrm{S}}$ ratios, we used the $V_{\mathrm{P}}$ and $V_{\mathrm{S}}$ models to develop a Poisson's ratio model along the seismic profile (fig. 8). We calculated Poisson's ratios from the relationship between $V_{\mathrm{P}}$ and $V_{\mathrm{S}}$ as follows:

$$
\begin{aligned}
\mathrm{PR} & =3 \mathrm{~K}-2 \mu / 6 \mathrm{~K}+2 \mu \\
& =\left[\left(V_{\mathrm{P}} / V_{\mathrm{S}}\right)^{2}-2\right] /\left[2\left(V_{\mathrm{P}} / V_{\mathrm{S}}\right)^{2}-2\right],
\end{aligned}
$$

where

$$
\begin{aligned}
\text { PR } & \text { is Poisson's ratio, } \\
\mathrm{K} & \text { is the bulk modulus, } \\
\mu & \text { is the shear modulus, } \\
V_{\mathrm{P}} & \text { is the P-wave velocity, and } \\
V_{\mathrm{S}} & \text { is the S-wave velocity. }
\end{aligned}
$$

Because of the lower resolution of our $V_{\mathrm{S}}$ model, our Poisson's ratio model is also limited in resolution.

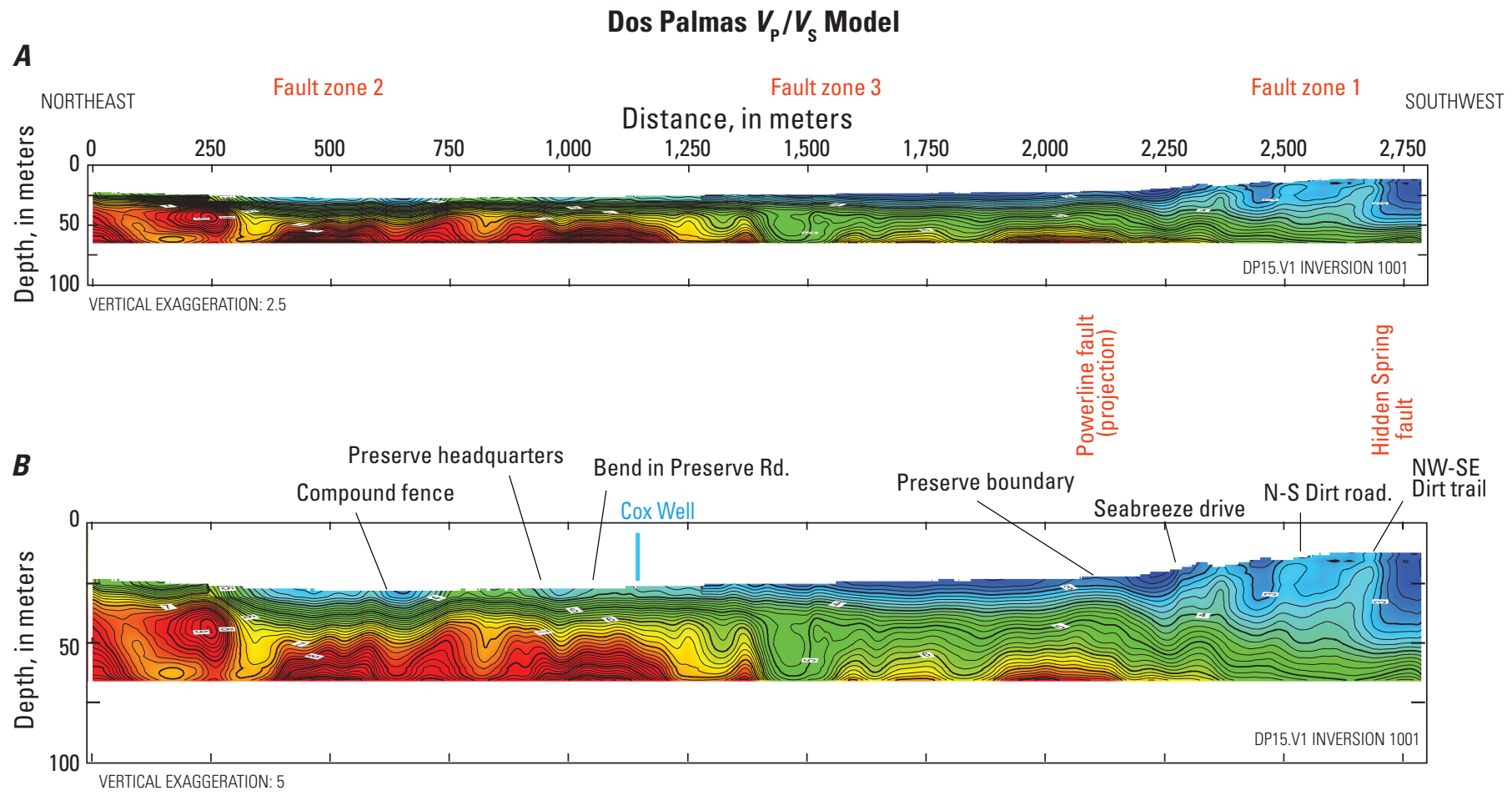

EXPLANATION $V_{\mathrm{p}} / V_{\mathrm{s}}$ Ratios

\section{0}

3.5

5.0

6.5
Figure 7. Plots of $V_{p} / V_{s}$ ratio model along the Dos Palmas Preserve seismic profile. Depth (left axis) is relative to a datum about $10 \mathrm{~m}$ above the topographically highest point along the seismic profile; land surface is approximately at top of colored contours. $A$, Model plotted with 2.5x vertical exaggeration (VE). $B$, Model plotted with $5 x$ vertical exaggeration. Landmarks along the seismic profile are shown along top axis. 


\section{Dos Palmas Poisson's Ratio Model}

A

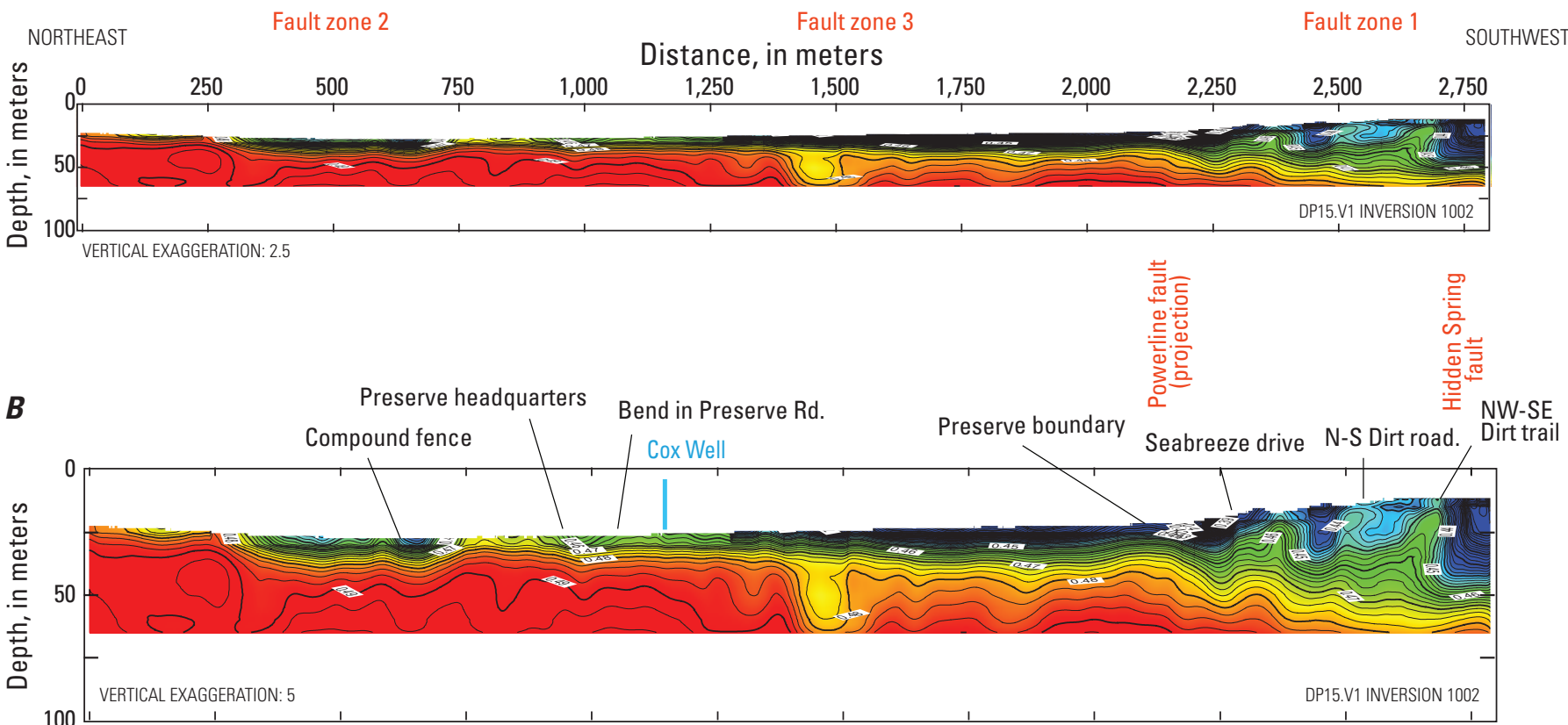

\section{EXPLANATION}

Poisson's Ratio

0.430
0.445
0.460
0.475
0.490

Figure 8. Plots of Poisson's ratio model along the Dos Palmas Preserve seismic profile. Depth (left axis) is relative to a datum about $10 \mathrm{~m}$ above the topographically highest point along the seismic profile; land surface is approximately at top of colored contours. $A$, Model plotted with $2.5 x$ vertical exaggeration (VE). $B$, Model plotted with $5 \mathrm{x}$ vertical exaggeration. Landmarks along the seismic profile are shown along top axis.

\section{Reflection Processing}

We developed a seismic reflection stack along the seismic profile (fig. 9) using the P-wave waveforms from our seismic survey and the tomographic $V_{\mathrm{p}}$ model shown in figure 5 . Processing steps included trace editing; timing corrections; elevation static corrections; automatic gain control (AGC); bandpass filtering; top, bottom, and surgical muting; velocity analysis (from refractions); normal-move-out correction; stretch muting; common-depth-point stacking; post-stack AGC; post-stack bandpass filtering; and post-stack deconvolution. For velocities at depths in excess of those determined by the tomography velocity model, we used parabolic estimates, and we inferred velocities based on laboratory-determined velocity-depth (pressure) relations (Carmichael, 1989). Fold (a measure of the redundancy of common midpoint reflections) averages about 100 along most of the seismic reflection profile, with maximum fold as great as 180 near the center of the profile. Near the ends of the profile, however, fold decreases to near one. Because of the 3-m shot and geophone spacings, the seismic reflection images have a common-depth-point spacing of $1.5 \mathrm{~m}$ along the entire 2,800 -m-long profile, thereby providing very high spatial resolution. We processed the seismic reflection data using ProMax ${ }^{\circledR}$, a commercial interactive data processing package.

\section{Seismic Models and Images}

Using the data modeling and processing methods on the acquired data, we developed models and images that measured velocities and imaged subsurface stratigraphy and structures that are important in evaluating groundwater and faulting in the Dos Palmas area. We briefly describe each of those models and images.

\section{Tomographic P-Wave Velocity $\left(V_{\mathrm{p}}\right)$ Model}

Our preferred $V_{\mathrm{p}}$ model (fig. 5) shows that $V_{\mathrm{p}}$ ranges from about 600 to 2,450 m/s in the upper approximately $75 \mathrm{~m}$ of the seismic profile. Generally, lower velocities were measured near the surface and higher velocities were measured at depth. On the northeast and southwest sides of the seismic profile, higher velocities were measured at shallower depths relative to the central part of the profile. At about meter 250 of the seismic profile, an approximately 200 -m-wide zone of relatively low velocities persists to the bottom of the velocity model, and similar zones with relatively low velocities are apparent near the southwest end of the model (meters 2,250 and 2,685); these velocity anomalies appear to correspond to significant structural features discussed later in this report. Additionally, 


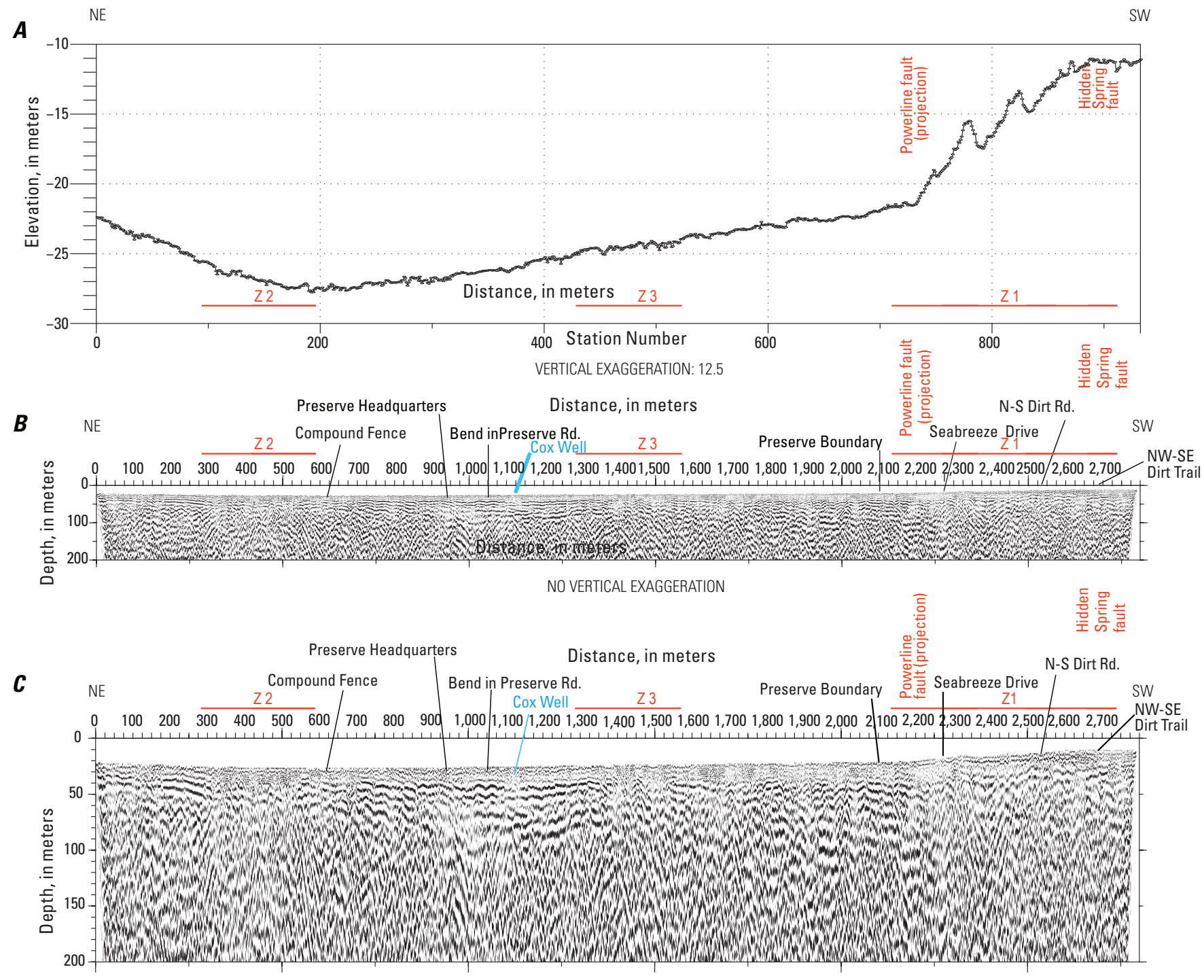

VERTICAL EXAGGERATION: 3

Figure 9. Plots of topography and seismic reflection along the Dos Palmas Preserve seismic profile. Horizontal red lines labeled Z1, Z2, and Z3 show interpreted fault zones. $A$, Topography showing slope direction changes along the seismic profile. $B, C$, Seismic reflection stacks plotted without vertical exaggeration $(B)$ and with $3 x$ vertical exaggeration $(C)$. Depth (left axis) is relative to a datum about $10 \mathrm{~m}$ above the topographically highest point along the seismic profile; land surface is approximately at top of reflection images. Landmarks along the seismic profile, including the perpendicular projection of the Cox well, are shown along top axis. Interpreted fault zones (Z1, Z2, and Z3) result in long-scale $(>100 \mathrm{~m})$ dip changes of reflective layers, but apparent offsets in reflections likely result from faulting in multiple places along the seismic profile. Near-vertical alignments of diffractions (inverted $V$ pattern) are consistent with near-vertical faults, which are particularly abundant beneath the interpreted fault zones. 
there are smaller anomalies along much of the central lower part of the seismic profile that also imply structure. P-wave velocity, particularly the $1,500 \mathrm{~m} / \mathrm{s} V_{\mathrm{P}}$ contour, is important in evaluating groundwater and subsurface faulting in sedimentary basins, as discussed below.

\section{MASW S-Wave Velocity $\left(V_{s}\right)$ Model}

Our preferred $V_{\mathrm{S}}$ model shows that $V_{\mathrm{S}}$ ranges from about 150 to $250 \mathrm{~m} / \mathrm{s}$ in the upper about $50 \mathrm{~m}$ along the seismic profile (fig. 6). Generally, the lower velocities were measured at shallow depths on the northeast half of the model, with higher velocities on the southwest half of the model near its base. As similarly seen for the $V_{\mathrm{p}}$ model, the highest $V_{\mathrm{S}}$ was measured southwest of meter 2,250. Near the base of the $V_{\mathrm{S}}$ model, there are laterally discrete zones of relatively low and high velocities $(300 \mathrm{~m} / \mathrm{s}$ to as high as $550 \mathrm{~m} / \mathrm{s})$ that likely represent structural and stratigraphic variations, including fault zones. We note that the $V_{\mathrm{s}}$ model is not as well resolved as the $V_{\mathrm{P}}$ model because the CMPCC gathers used to develop the $V_{\mathrm{S}}$ model are averaged over a 30-m span, whereas there are only 3-m intervals between shot gathers used to develop the $V_{\mathrm{P}}$ model along the entire 2,800-m-long seismic profile. In addition, the $V_{\mathrm{S}}$ model was constructed from surface waves, which generally provide lower resolution.

\section{$V_{\mathrm{p}} / V_{\mathrm{s}}$ Ratio Models}

$V_{\mathrm{p}} / V_{\mathrm{S}}$ ratios range from about 3.2 to 9.2 , with the lowest ratios predominantly in the southwestern half of the model near the surface (fig. 7). The observed $V_{\mathrm{p}} / V_{\mathrm{S}}$ ratios are large relative to those expected for rocks $(\sim 1.4-1.8)$, but most are in the expected range for saturated, unconsolidated sediments. $V_{\mathrm{P}} / V_{\mathrm{S}}$ ratios are highly variable in saturated, unconsolidated sediments and clays (Stumpel and others, 1984; Catchings and Lee, 1996; Uyanik, 2011; Catchings and others, 2014; Pasquet and others, 2015), but high values $(>6)$ calculated at discrete locations and depths $(>25 \mathrm{~m})$ along our model are atypical of shallow clastic sediments (see discussion below) and may be related to fault zones (Catchings and others, 2014) and (or) localized saturated clays (Stumpel and others, 1984).

\section{Poisson's Ratio Model}

Our Poisson's ratio model (fig. 8) shows relatively high values along the entire seismic profile, with minimum values of about 0.385 in the southwestern half (at shallow depths) and maximum values of about 0.495 near the northeast end ( $\sim 20-40 \mathrm{~m}$ below the surface). Poisson's ratio for materials can vary widely, but the maximum value of 0.5 typically correlates with materials that lack a shear modulus, such as fluids or gasses, and values near 0.5 at Dos Palmas Preserve likely represent highly water-saturated subsurface materials. Thus, models of Poisson's ratio can be useful in inferring the lithology, structure, and physical condition of the shallow subsurface.

\section{Seismic Reflection Images}

The shallow subsurface is highly reflective to depths of 13 to $30 \mathrm{~m}$ (fig. 9), below which, stratigraphic layers appear significantly thicker, with numerous diffractions in many places. A diffraction is a hyperbolic pattern on unmigrated seismic reflection images that looks somewhat like an inverted V (fig. 10). Diffraction occurs when a seismic wave impinges on a sharp object in the subsurface, such as a stratigraphic layer that has been vertically offset by faulting, wide fractures, or the edge of an erosion channel. When a series of layers are near-vertically offset, there is typically a near-vertical alignment of diffractions. Such a pattern is observed in several places along the seismic profile below about $25 \mathrm{~m}$ depth and in some places near the surface (fig. 9). Because of the long length and shallow imaging depth of the reflection image, we recommend the reflection image (fig. $9 B$ ) be viewed at an expanded scale without vertical exaggeration.
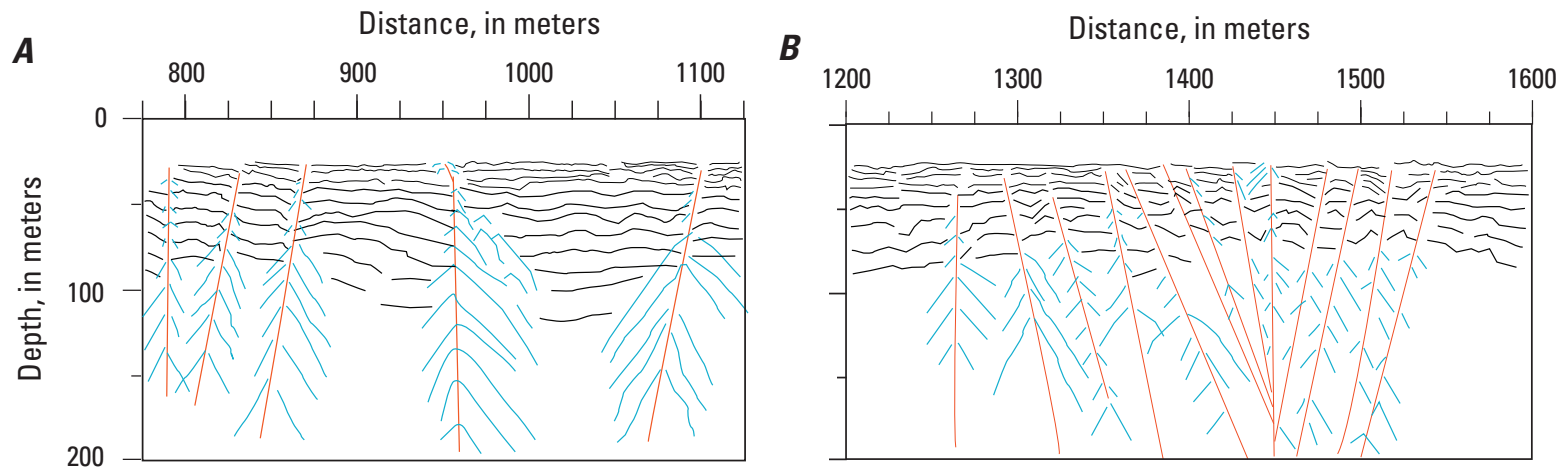

Figure 10. Example line drawings from two areas along the seismic reflection image of the Dos Palmas Preserve seismic profile shown in figure $9 B$, plotted without vertical exaggeration. Black lines show traces of reflectors; red lines show faults interpreted based on offset of reflectors; blue lines show traces of diffractions seen on the seismic image. $A$, Line drawings from about meters 800 to 1,100 of the seismic profile. $B$, Line drawings from about meters 1,200 to 1,600 of the seismic profile. 


\section{Discussion and Interpretations}

Our seismic images show that the upper $200 \mathrm{~m}$ of the subsurface are complex, with folded, fractured, and faulted strata. Because of the complexity of the subsurface structure, interpretation of the seismic reflection image is challenging. To better understand the subsurface along the seismic profile, we combined our available seismic data (velocities, velocity ratios, reflection) with known geology to provide an interpretative model.

\section{Seismic Inferences for Shallow Stratigraphy}

Geologic mapping (fig. 2B) shows that surface geologic materials consist of Quaternary (Holocene) alluvium overlying Quaternary (Pleistocene to Early Holocene) Lake Cahuilla sand and silt deposits, which range in composition from clayey silt to unlithified pebble conglomerate (Babcock, 1974). On the seismic images, we suggest these Quaternary sediments are low-velocity, slightly reflective deposits that extend to about 25-30 m depth in the central part of the seismic profile (figs. 11, 12). On the alluvial fans near the mountains, the Quaternary alluvium consists of reworked Lake Cahuilla sand and coarse, bouldery alluvium, some of which may extend into the area of the seismic profile and may also account for some of the diffractions seen on the seismic reflection image above $25 \mathrm{~m}$ depth (figs. 9, 10). However, most of the diffractions align near vertically and extend to depths greater than the likely extent of the Lake Cahuilla sediments, indicating a high probability that the diffractions arise from breaks in the stratigraphic section, such as would be caused by near-vertical faulting or strata offset by channel erosion (fig. 10).

Geologic mapping by Babcock (1974) shows that the Lake Cahuilla sediments are underlain by the Borrego Formation, which is tilted and folded with moderate to steeply $\left(30^{\circ}\right.$ to $76^{\circ}$ ) dipping beds where it is exposed at nearby Salt Creek (fig. 2B). The Borrego Formation is a brackish-water lacustrine deposit that includes evaporite layers interbedded with clay and silt (Babcock, 1974). Underlying the Borrego Formation is the Pliocene-Pleistocene Shavers Well Formation, which consists of coarse clastic materials derived from the ranges east of the Chocolate and Orocopia Mountains (Babcock, 1974). The rocks of the Shavers Well Formation were also tilted and eroded prior to deposition of the Borrego Formation. Such titling, erosion, and faulting would make reflection images of the Borrego and Shavers Well formations, and of rocks underlying these formations, unclear and diffractive. The diffractive, higher velocity, and disrupted layering below about 25-30 m depth (figs. 10-12) may correlate with the top of the Borrego Formation. According to Babcock (1974), in the nearby Mecca Hills, there are tightly folded clastic rocks that are cut by numerous closely spaced traces of the San Andreas Fault, and he further suggests that style of deformation continues with little change southward into the Dos Palmas Preserve area. Thus, faults, folds, and steep dips likely exist beneath, if not within, the Quaternary alluvium along much of the seismic profile.

\section{Seismic Inferences for Groundwater}

Information about groundwater can be inferred from multimode seismic data, particularly on the basis of $V_{\mathrm{p}}, V_{\mathrm{S}}$, $V_{\mathrm{p}} / V_{\mathrm{s}}$, and Poisson's ratio models and reflection images. Of particular importance is the $1,500 \mathrm{~m} / \mathrm{s}$ velocity contour of the $V_{\mathrm{P}}$ model, which can be diagnostic of the top of the shallowest thick groundwater aquifer at Dos Palmas Preserve.

\section{$V_{\mathrm{p}}$ and $V_{\mathrm{S}}$ Models and Groundwater}

Although many seismic studies have inferred a range of $V_{\mathrm{P}}(\sim 1,000-2,100 \mathrm{~m} / \mathrm{s})$ for the top of groundwater in shallow sediments (Stumpel and others, 1984; Haeni, 1986; Green and others, 1999; Garambois and others, 2002; Turesson, 2007; Grelle and Guadagno, 2009; Pasquet and others, 2015), most studies indicate a narrower range of $V_{\mathrm{P}}(\sim 1,500-1,700 \mathrm{~m} / \mathrm{s})$ for saturated sediments. The studies indicating a wider $V_{\mathrm{p}}$ range typically use older 1-dimensional or forward modeling techniques to evaluate the $V_{\mathrm{p}}$ data, or those studies use rather low-resolution (wide shot and [or] sensor spacing) acquisition and processing techniques, which can result in a wide range of velocities for the saturated sediments. However, we have observed from high-resolution seismic tomography studies (with corresponding well data) that the $1,500 \mathrm{~m} / \mathrm{s} V_{\mathrm{p}}$ contour strongly correlates with the top of thick sections of groundwater (for example, Catchings and others, 1999a,b, 2000, 2001, 2006, 2007, 2008, 2009, 2010, 2013, 2014; Gandhok and others, 1999; Christensen and others, 2015; Rosa and others, 2016). The depth of the $1,500 \mathrm{~m} / \mathrm{s} V_{\mathrm{P}}$ contour in our model (figs. $5,11,12)$ suggests that the shallowest thick $(>\sim 5 \mathrm{~m})$ aquifer varies in depth from about 13 to $30 \mathrm{~m}$ below the ground surface along the seismic profile, with greater depths near the central part of the profile and shallower depths near the northeastern and southwestern ends. The closest well to the seismic profile was the Cox well (fig. 4), which does not have available driller's logs, documented well-construction details, or known depths for the source aquifers (Richard Shatz and Richard Putty, written commun., Montgomery Watson Harza and GEI Consultants, 2009). However, projection of the geology from other wells onto the seismic profile suggests that the water source for the Cox well may be from upper and middle confined aquifers, the tops of which are believed to be at 0 $\mathrm{m}$ and about $18 \mathrm{~m}$ depth, respectively, at the well (Shatz and Putty, written commun., 2009). The upper confined aquifer is thought to be an Artesian water mound that is limited in extent to the immediate vicinity of the well, and therefore, it would not be observed along the seismic profile, which was offset from the well by about 45 to $60 \mathrm{~m}$. The middle confined aquifer, however, is thought to extend far beyond the Dos Palmas Preserve, and Shatz and Putty (written commun., 2009) project the middle aquifer to be about $18 \mathrm{~m}$ deep at the Cox well, consistent with the top of groundwater (19 m depth) inferred from the $1,500 \mathrm{~m} / \mathrm{s} V_{\mathrm{P}}$ contour of our tomography model (fig. 12). Herein, we suggest that the $1,500 \mathrm{~m} / \mathrm{s} V_{\mathrm{P}}$ contour in our model represents the top of the middle aquifer. 


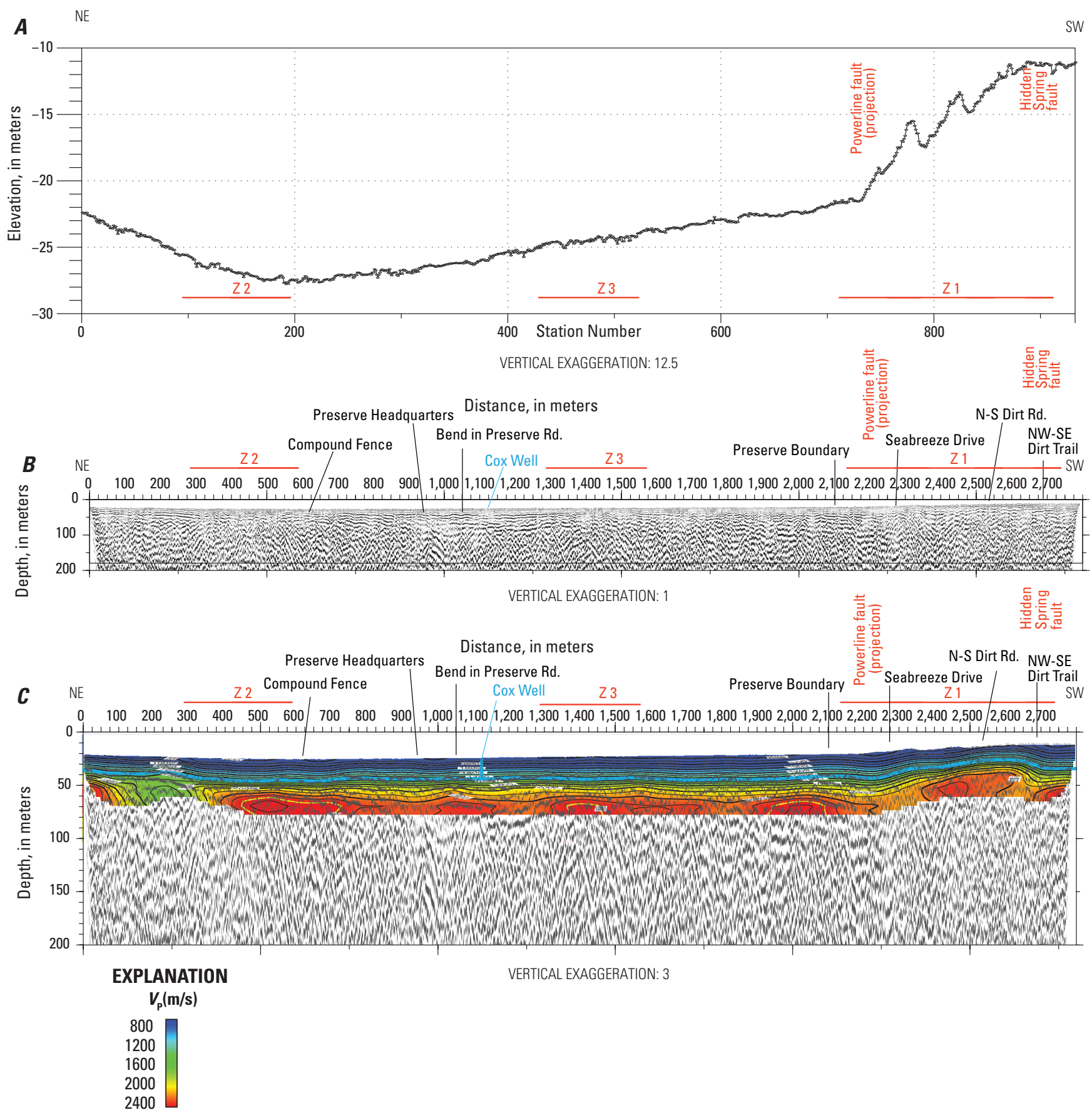

Figure 11. Comparison plots of topography, seismic reflection, and $\mathrm{P}$-wave velocity $\left(V_{\mathrm{p}}\right)$ along the Dos Palmas Preserve seismic profile; land surface is approximately at top of reflection images. Horizontal red lines labeled Z1, Z2, and Z3 show interpreted fault zones. $A$, Topography along the seismic profile. $B$, Seismic reflection stack from figure $9 B$, plotted without vertical exaggeration. Vertical blue line shows the nearest projection of the Cox well onto the seismic profile. $C$, Seismic reflection stack from figure $9 C$ with the $V_{p}$ model (in meters per second [m/s]) from figure 5 superimposed. Both are plotted with $3 x$ vertical exaggeration. Subhorizontal blue line about 13-30 m depth beneath the surface highlights the 1,500 meters per second $(\mathrm{m} / \mathrm{s}) V_{\mathrm{p}}$ contour. Near the Cox well, the $1,500 \mathrm{~m} / \mathrm{s} V_{\mathrm{p}}$ contour correlates with depth to the top of the first main aquifer, based on projections by Shatz and Putty (written commun., 2009). 


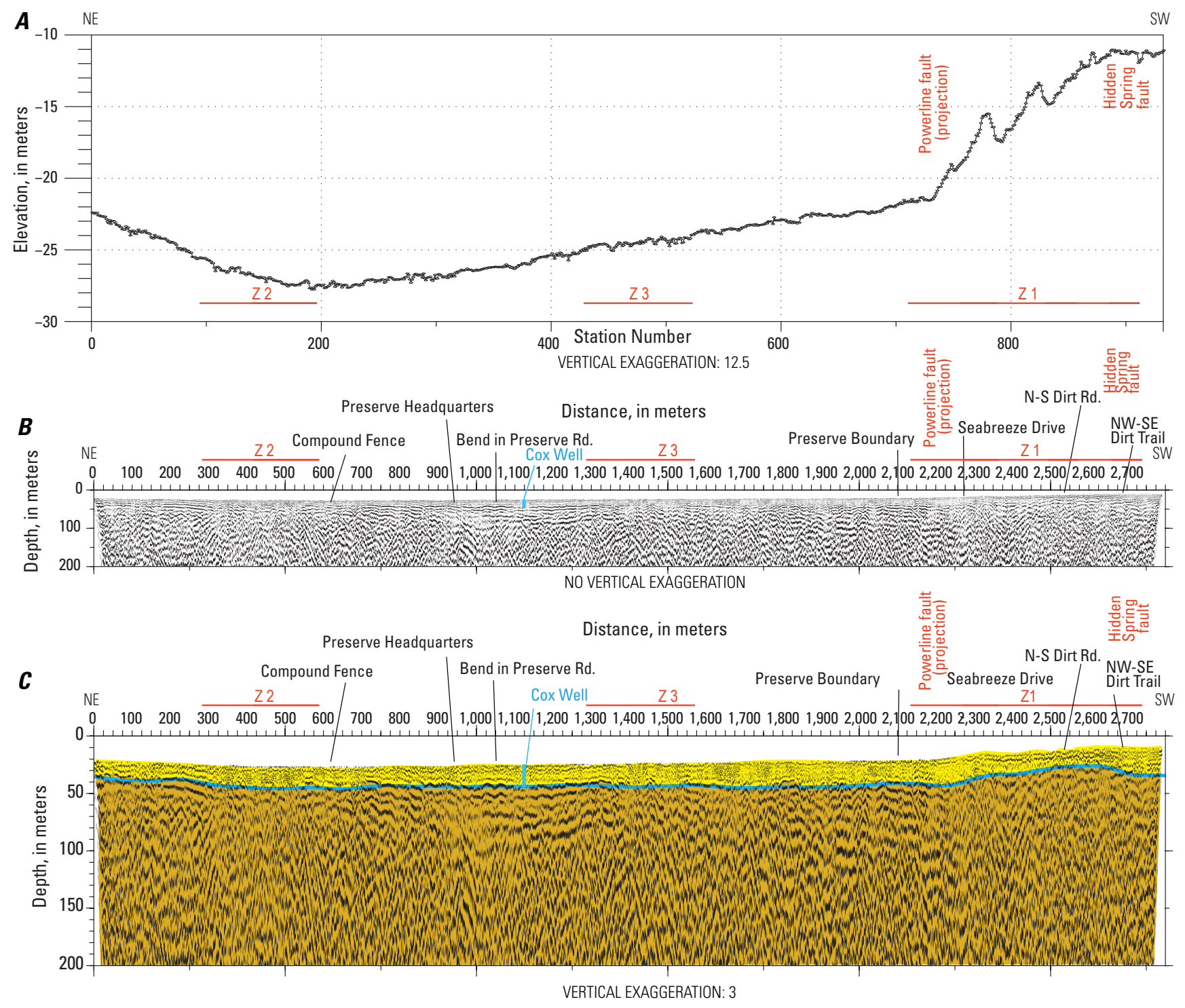

Figure 12. Comparison plots of topography, seismic reflection, and interpretive stratigraphy along the Dos Palmas Preserve seismic profile; land surface is approximately at top of reflection images. Horizontal red lines labeled Z1, Z2, and Z3 show interpreted fault zones. $A$, Topography along the seismic profile. $B$, Seismic reflection stack from figure $9 B$, plotted without vertical exaggeration. Vertical blue line shows the nearest projection of the Cox well onto the seismic profile. $C$, Seismic reflection stack from figure $9 C$ with interpretative stratigraphy and the interpreted depth of the top of the main aquifer superimposed. Light yellow area is interpreted as unconsolidated and unsaturated alluvium. Upper part of the dark yellow area is interpreted as consolidated and water-saturated sediments. Subhorizontal blue line about 13-30 m depth beneath the surface highlights the 1,500 meters per second $(\mathrm{m} / \mathrm{s}) V_{p}$ contour from figure 5 . Near the Cox well, the $1,500 \mathrm{~m} / \mathrm{s} V_{p}$ contour correlates with depth to the top of the first main aquifer, based on projections by Shatz and Putty (written commun., 2009). 
From other tomography studies, we have found that sediments with higher $V_{\mathrm{p}}(\sim 2,500-2,800 \mathrm{~m} / \mathrm{s})$ generally correlate with geologic materials that are too dense to form productive aquifers, such as low-porosity sedimentary rocks or weathered crystalline rocks. Along the seismic profile, the highest $V_{\mathrm{P}}$ $(\sim 2,300-2,450 \mathrm{~m} / \mathrm{s})$ was measured in discrete zones at depths greater than $25 \mathrm{~m}$, suggesting that the bottom of the aquifer system was not imaged with $V_{\mathrm{p}}$ tomography. These higher $V_{\mathrm{P}}$ layers (fig. 11) generally correlate with a laterally continuous reflector (fig. 12) but not necessarily with relatively higher $V_{\mathrm{S}}$ layers (fig. 13), suggesting that productive aquifers may be more than $10 \mathrm{~m}$ thick. As suggested by Shatz and Putty (written commun., 2009), we note that there may be more than one aquifer along the seismic profile, but individual aquifers would not be imaged with $V_{\mathrm{p}}$ tomography unless the aquifer is sufficiently thick to transmit the seismic P-wave. On the reflection image, there may be reflectors that correlate with more than one aquifer, but without well data, it is difficult to correlate the reflectors with other aquifers.

\section{Reflection Images and Groundwater}

On reflection images, the top of the saturated zone commonly forms an impedance contrast owing to the sudden increase in velocity caused by saturated sediments. Along the seismic profile, strong reflectors are seen at the top of the apparent middle aquifer, as indicated by the $1,500 \mathrm{~m} / \mathrm{s}$ velocity contour (figs. 9, 11, 12). Although the 1,500 m/s velocity contour is somewhat smoothed, strata (as seen on the reflection image) with velocities less than $1,500 \mathrm{~m} / \mathrm{s}$ appear to be more continuous and have thinner layers, but strata with velocities greater than $1,500 \mathrm{~m} / \mathrm{s}$ velocity have thicker layering and are highly diffractive on the reflection images (figs. 11, 12). The apparent middle aquifer $(1,500 \mathrm{~m} / \mathrm{s})$ appears to form mostly continuous reflectors (with vertical offsets) across the entire seismic profile.

\section{VP/VS Ratios and Groundwater}

We expect relatively high $V_{\mathrm{P}} / V_{\mathrm{S}}$ ratio values in watersaturated, unconsolidated sediments because $V_{\mathrm{P}}$ should be $1,500 \mathrm{~m} / \mathrm{s}$ or greater for the saturated sediments (figs. 11, 12), but $V_{\mathrm{S}}$ should be low $(\sim 600 \mathrm{~m} / \mathrm{s}$ or less) for the same sediments (fig. 13). The actual value of $V_{\mathrm{S}}$ will vary depending on the composition, compaction, and degree of saturation of the sediments. This is generally the case because $V_{\mathrm{S}}$ increases with more rigid materials and with the degree of compaction, but $V_{\mathrm{S}}$ decreases slightly with increasing saturation relative to dry sediments (Nur, 1982; Zhu and others, 2000). Along the seismic profile, we observe that $V_{\mathrm{p}} / V_{\mathrm{S}}$ ratios exceed 2.5 nearly everywhere except the nearest surface on the southwestern side of the profile and west of the Hidden Spring fault, but we do not observe a strong correlation between a given $V_{\mathrm{P}} / V_{\mathrm{S}}$ ratio and the interpreted aquifer (figs. 7, 14). At the Cox well, we find that the top of the aquifer $(1,500 \mathrm{~m} / \mathrm{s})$ correlates with a
$V_{\mathrm{p}} / V_{\mathrm{S}}$ ratio of about 6.75 , but just a few hundred meters to the southwest, the top of the aquifer $(1,500 \mathrm{~m} / \mathrm{s})$ has a $V_{\mathrm{p}} / V_{\mathrm{S}}$ ratio of about 5.0 (compare figs. 11,12,14), suggesting a significant change in lithology or physical condition of the saturated sediments southwest of the Cox well.

\section{Poisson's Ratio and Groundwater}

Catchings and others $(2006 ; 2014)$ showed the top of groundwater table in unconsolidated, water-saturated sediments typically has a Poisson's ratio (PR) value greater than about 0.43, and Bowles (1982) and Pasquet and others (2015) suggest Poisson's ratio for saturated soils is typically greater than 0.45 . Lithological variations may account for the observed differences in the Poisson's ratio for saturated materials in the shallow subsurface (Stumpel and others, 1984; Catchings and Lee, 1996; Salem, 2000; Uyanik, 2011), but for this study, we consider values greater than 0.43 to indicate saturated subsurface materials or partially saturated clay-rich materials. Accordingly, our Poisson's ratio model (figs. 8, 15) suggests there are at least partially saturated soils and (or) clay $(\mathrm{PR}=0.43-0.49)$ at relatively shallow depths $(<5 \mathrm{~m})$ along most of the seismic profile, but near the northeast end of the profile and at discrete locations along the profile (including near the southwest end of the profile), the upper few meters of the subsurface likely consists of sands or clay that were saturated or partially saturated at the time of seismic data acquisition. On the basis of the $1,500 \mathrm{~m} / \mathrm{s} V_{\mathrm{p}}$ contour (figs. 5, 11), however, the aquifer appears to be as deep as $25 \mathrm{~m}$ in places along the seismic profile, suggesting that although there may be at least partial groundwater saturation at shallow $(<10 \mathrm{~m})$ depths (likely owing to flow from the Coachella Canal; see fig. 4), the main aquifer is deeper than inferred from the 0.43 Poisson's ratio contour. Shallow, highly saturated strata do not necessarily coincide with the regional aquifer, especially where there is an overlying localized (thin) aquifer. At the Cox well, the deeper aquifer appears to correlate with a Poisson's ratio value of 0.4875 and a $V_{\mathrm{p}}$ of $1,500 \mathrm{~m} / \mathrm{s}$. The difference in the depth of the deeper aquifer, as inferred by the $1,500 \mathrm{~m} / \mathrm{s}$ $V_{\mathrm{P}}$ contour and the 0.43 Poisson's ratio value, is likely due to thin perched aquifers above the thicker deep aquifer; these thin perched aquifers are likely too thin (individually) to propagate seismic waves at higher velocities. Such thin aquifers (for example, sand layers over evaporites or clays) may form when water flowing from the Coachella Canal (fig. 4) does not fully saturate all of the strata above the aquifer. Partially saturated strata above the aquifer would yield an average $V_{\mathrm{P}}$ less than $1,500 \mathrm{~m} / \mathrm{s}$ because a relatively thick zone of fully saturated strata is required to propagate the $\mathrm{P}$-wave at that velocity. High Poisson's ratio values could also be caused by clay aquitards between perched aquifers, as partially saturated clays are known to exhibit high Poisson's ratio values (Stumpel and others, 1984), but in such a case, the $V_{\mathrm{P}}$ would not be that of a fully saturated sequence of sediments $(1,500 \mathrm{~m} / \mathrm{s})$. Along the seismic profile, zones of relatively low Poisson's ratio values $(<0.43)$ in the upper about $10 \mathrm{~m}$ thicken from the center of the 
profile southwestward. At about the same location near the center of the profile, surface materials generally change from dominantly silt to dominantly sand (Babcock, 1974; fig. 2B).

\section{Seismic Inferences for Faulting}

Individually, $V_{\mathrm{p}}, V_{\mathrm{S}}, V_{\mathrm{p}} / V_{\mathrm{S}}$ ratios, and reflection images, such as those presented in this report, can be indicative of faulting in the shallow subsurface, and when all of these images are consistent with subsurface faulting, we have high confidence in our interpretations of faulting along the seismic profile.

\section{$V_{\mathrm{p}^{\prime}} V_{\mathrm{s}^{\prime}}$ and $V_{\mathrm{p}} / V_{\mathrm{s}}$ Ratio Models and Faulting}

For tomographic images of unconsolidated sediments, a diagnostic indicator of faulting is an abrupt change in the depth of the $1,500 \mathrm{~m} / \mathrm{s} V_{\mathrm{p}}$ contour, which usually coincides with the top of groundwater. The top of groundwater is commonly vertically offset across faults because faults are usually groundwater barriers (for example along the San Andreas Fault, see Catchings and others, 2009, 2014; Philibosian and others, 2011). Along the seismic profile, there are vertical offsets in the $1,500 \mathrm{~m} / \mathrm{s}$ velocity contour in multiple locations, many of which likely result from faulting. In addition, in tomographic images, faults are typically seen as near-vertical or steeply dipping zones of relatively low velocity, particularly for rocks that have $V_{\mathrm{p}}$ of about 2,500 $\mathrm{m} / \mathrm{s}$ or greater (Catchings and others, 1998; 2014). Although the highest values of $V_{\mathrm{P}}$ along the seismic profile are slightly less than $2,500 \mathrm{~m} / \mathrm{s}$, nearvertical zones of relatively low velocity are seen in multiple locations along the seismic profile, primarily in the deeper, higher velocity $(>2,000 \mathrm{~m} / \mathrm{s})$ rocks (fig. 5 ). We suggest that these near-vertical zones of low $V_{\mathrm{P}}$ in the higher velocity rocks are likely caused by faulting.

Similarly, in our tomographic $V_{\mathrm{S}}$ model, we observe near-vertical zones of low $V_{\mathrm{S}}$ at discrete locations along the seismic profile. For nearly all ranges of $V_{\mathrm{s}}$, there is a reduction of $V_{\mathrm{S}}$ within fault zones because mechanical grinding during the faulting process causes a reduction in the shear modulus of rocks. Thus, the observed multiple near-vertical zones of low $V_{\mathrm{S}}$ along the seismic profile are also strong indicators of faulting. However, as discussed above, the MASW $V_{\mathrm{S}}$ model is not as well resolved as the tomographic $V_{\mathrm{P}}$ model, and from other studies, we have found that the MASW $V_{\mathrm{S}}$ model can slightly offset low- or high-velocity anomalies in a lateral sense; thus, there may be slight lateral offsets in the high-velocity $V_{\mathrm{P}}$ and low-velocity $V_{\mathrm{S}}$ anomalies.

Mechanical grinding during faulting also results in a modest reduction in $V_{\mathrm{P}}$ within fault zones, unless the fault zone is at least 90 percent water saturated (Nur and Simmons, 1969). For water-saturated faults, $V_{\mathrm{p}}$ can be as high as that of the same unfaulted rock, and in the case of faulted and saturated sediments, $V_{\mathrm{P}}$ is at least $1,500 \mathrm{~m} / \mathrm{s}$. The resulting relatively high $V_{\mathrm{P}}$ and relatively low $V_{\mathrm{S}}$ in water-saturated fault zones results in $V_{\mathrm{p}} / V_{\mathrm{S}}$ ratios that are unusually large (as great as 10), and such high $V_{\mathrm{P}} / V_{\mathrm{S}}$ ratios can be diagnostic of faulting (Catchings, and others, 2014). This is commonly observed when the areas of high $V_{\mathrm{P}} / V_{\mathrm{S}}$ ratios are measured in discrete near-vertical zones. We observe such discrete near-vertical zones of high $V_{\mathrm{p}} / V_{\mathrm{S}}$ ratios in multiple locations along the $V_{\mathrm{p}} / V_{\mathrm{S}}$ ratio image of the seismic profile (see fig. 7).

\section{Reflection Images and Faulting}

On reflection images with subhorizontally layered strata, faults are usually indicated by vertically offset reflectors, especially when a series of laterally continuous reflectors are vertically offset over an appreciable range of depths. In addition, for unmigrated reflection images, the vertically offset reflectors commonly include vertically aligned diffractions that originate at the intersections of the fault and the offset strata. Finally, abrupt changes in the dips of reflectors can also be strong indicators of faulting. Along the Dos Palmas Preserve seismic reflection image, we observe several places with vertically offset reflectors, and associated diffractions are coupled with variations in the dips of the associated strata across the apparent faults (figs. 9, 10). Although other features, such as deep, narrow subsurface channels, may give rise to similar diffraction patterns, vertical offsets of strata and changes in dip of strata would not normally be observed across a subsurface channel. Along the seismic profile, we observe multiple locations with apparent offset strata, coupled with diffractions, on the reflection image.

\section{Combined Images and Faulting Along the Seismic Profile}

Along the seismic profile, we observe strong indicators of faulting that are co-located geographically, including areas of high $V_{\mathrm{p}} / V_{\mathrm{S}}$ ratios, high Poisson's ratio values, near-vertical low $V_{\mathrm{S}}$ zones (and low $V_{\mathrm{p}}$ zones for parts of the model with $V_{\mathrm{P}}$ $2,000 \mathrm{~m} / \mathrm{s}$ or greater), combined with offset reflectors and diffractions on reflection images. On the basis of these multiple seismic observations, we suggest there are at least three significant fault zones, as well as other smaller fault traces along the seismic profile. The concept of closely spaced faults adjacent to the San Andreas Fault is consistent with the geologic mapping by Babcock (1974), who suggests that numerous closely spaced faults observed in the nearby Mecca Hills should also extend beneath the surface in the Dos Palmas Preserve area.

Several mapped faults cut through the general Dos Palmas Preserve area. One of the faults, the Hidden Spring fault, is mapped as crossing the seismic profile, and two other faults are mapped to the south of the profile (Babcock, 1974), the northward projections of which likely cross the profile (fig. $2 B$ ). The western trace of the Hidden Spring fault crosses the profile at about meter 2,700 (fig. 4), where our $V_{\mathrm{p}}$ (figs. $5,11)$ and $V_{\mathrm{S}}$ (fig. 6,13 ) images show a strong lateral change in velocities. Our $V_{\mathrm{P}} / V_{\mathrm{S}}$ ratio model (figs. 7, 14), Poisson's 


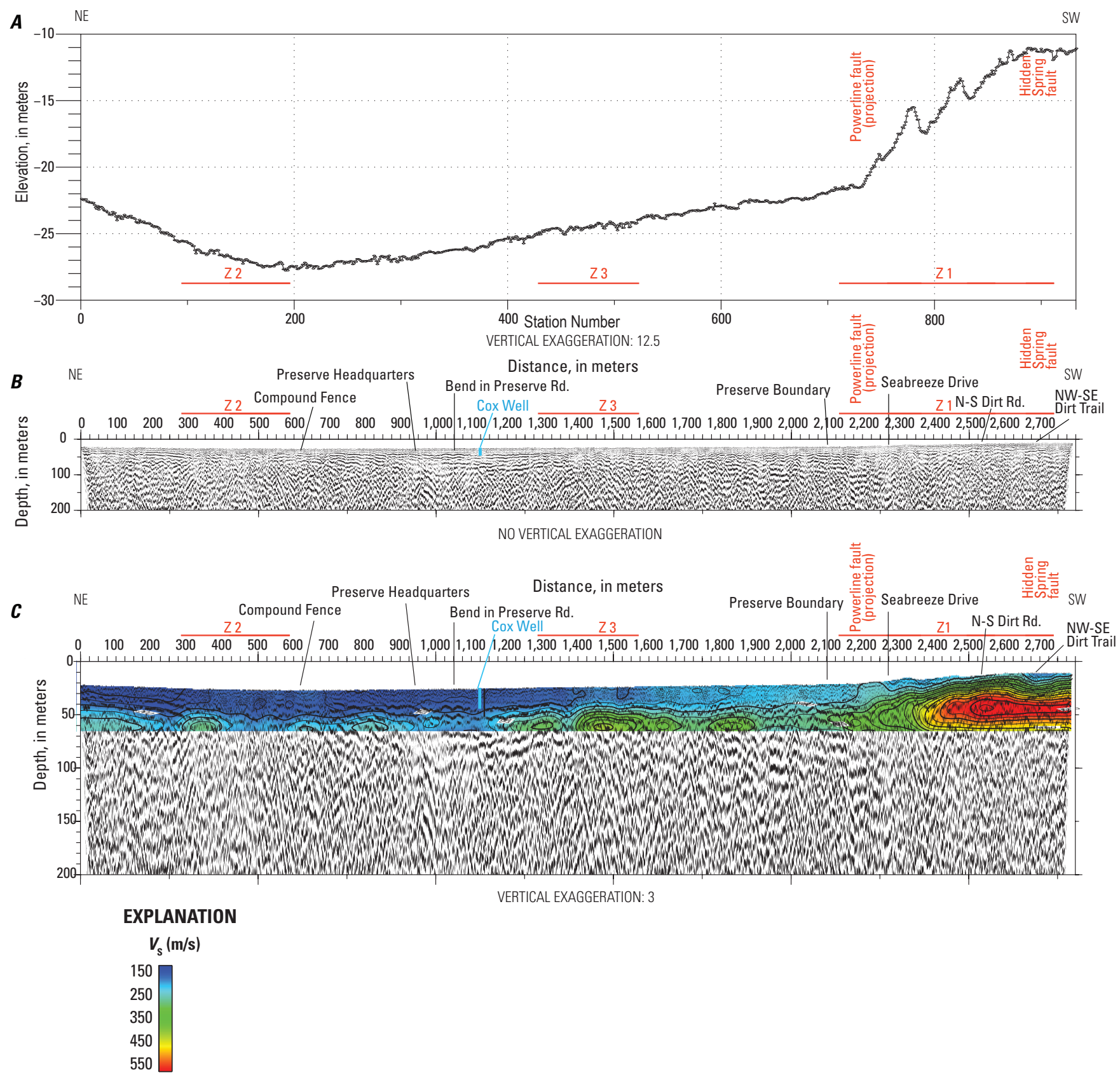

Figure 13. Comparison plots of topography, seismic reflection, and S-wave velocity $\left(V_{S}\right)$ along the Dos Palmas Preserve seismic profile; land surface is approximately at top of reflection images. Horizontal red lines labeled Z1, Z2, and Z3 show interpreted fault zones. $A$, Topography along the seismic profile. $B$, Seismic reflection stack from figure $9 B$, plotted without vertical exaggeration. Vertical blue line shows the nearest projection of the Cox well onto the seismic profile. $C$, Seismic reflection stack from figure $9 C$ with the $V_{s}$ model (in meters per second $[\mathrm{m} / \mathrm{s}]$ ) from figure 6 superimposed. Both are plotted with $3 x$ vertical exaggeration.

ratio model (figs. 8, 15), and reflection image (fig. 9) also show sharp lateral variations across the western trace of the Hidden Spring fault. All of the seismic images indicate abrupt down-to-the-southwest offsets. Northward projection of the Powerline fault (fig. $2 B$ ) indicates that it would cross the profile between meters 2,200 and 2,300, where we observe downto-the-northeast velocity anomalies (figs. 5, 7, 8) and reflectors (fig. 9). Between the western trace of the Hidden Spring fault and the projected Powerline fault, our seismic images suggest that the section has been uplifted relative to the remainder of the profile. This area appears to be an uplifted block (fig. $9 A$ ), but the velocity images $\left(V_{\mathrm{p}}\right.$ and $\left.V_{\mathrm{S}}\right)$, particularly the $V_{\mathrm{p}} / V_{\mathrm{S}}$ (fig. 7) and Poisson's ratio values (fig. 8), indicate lateral variations within the block that are consistent with additional 


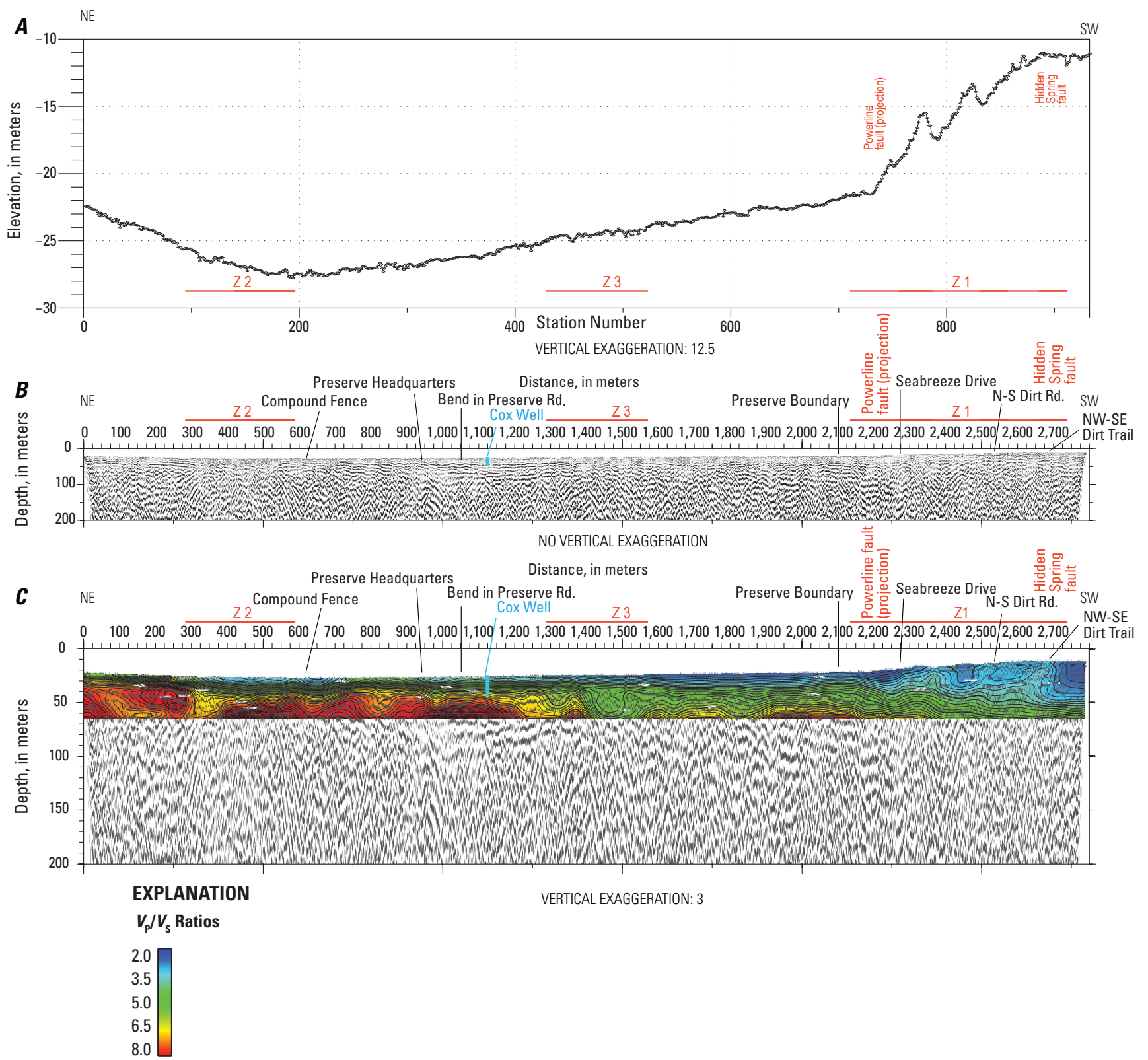

Figure 14. Comparison plots of topography, seismic reflection, and $V_{\mathrm{p}} / V_{\mathrm{s}}$ ratio along the Dos Palmas Preserve seismic profile; land surface is approximately at top of the reflection images. Horizontal red lines labeled Z1, Z2, and Z3 show interpreted fault zones. $A$, Topography along the seismic profile. $B$, Seismic reflection stack from figure $9 B$, plotted without vertical exaggeration. Vertical blue line shows the nearest projection of the Cox well onto the seismic profile. $C$, Seismic reflection stack from figure $9 C$ with the $V_{p} / V_{s}$ ratio model from figure 7 superimposed. Both are plotted with $3 x$ vertical exaggeration. Near the Cox well, a $V_{\mathrm{p}} / V_{\mathrm{s}}$ ratio of about 6.75 correlates with depth to the top of the first main aquifer, based on projections by Shatz and Putty (written commun., 2009). 
fault traces between the Hidden Spring and the Powerline faults. Topographic variations (fig. 9A) along this zone are also consistent with the presence of several fault traces between the Hidden Spring and projected Powerline faults. We also note that there are step-like variations in depth to the $1,500 \mathrm{~m} / \mathrm{s} V_{\mathrm{p}}$ contour (fig. 5), indicating lateral variations in the depth of the water table, possibly caused by faults that act as groundwater barriers. On the reflection image, apparent vertical offsets in reflectors between the Hidden Spring and projected Powerline faults correlate with near-vertical alignments of diffractions, which are also indicative of faults (fig. 10). Collectively, on the basis of our seismic data $\left(V_{\mathrm{p}}, V_{\mathrm{S}}, V_{\mathrm{P}} / V_{\mathrm{S}}\right.$ ratio, Poisson's ratio, and reflection images) and topography, we suggest that the Hidden Spring fault includes an about 500-m-wide zone of faults with several subparallel fault traces within an uplifted fault block. On our reflection image, we refer to this area as a zone of faults (Z1). Effectively, this overall structure forms a horst block and is consistent with the suggestion of Babcock (1974) that there are horst structures between the San Andreas, Hidden Spring, and Powerline faults.

Another apparent zone of prominent faulting is located near the eastern end of the seismic profile. From about meters 125 to 450 of the profile, the $V_{\mathrm{P}}$ seismic image (fig. 5) shows a significant down-to-the-southwest step in velocities, with a prominent zone of lower velocities near meter 250. Similar variations in $V_{\mathrm{s}}$ are seen between meters 125 and 600 (fig. 6), with lower velocities to the southwest. On the reflection image (fig. 9), at about meter 125 and between meters 250 and 600, there are disrupted reflectors with near-vertically aligned diffractions, and from about meters 300 to about 550, the reflectors are vertically offset, down to the southwest. The dip of the reflectors also changes between about meters 250 and 400. On the $V_{\mathrm{P}} / V_{\mathrm{S}}$ image (fig. 7), we observe a near-vertical offset in large $V_{\mathrm{p}} / V_{\mathrm{S}}$ ratio values (as great as 9) from meters 250 to about 450, with similar variations in Poisson's ratio values (fig. 8). In addition, topography changes substantially over this range (fig. 9A). Collectively, these anomalies suggest a zone of concentrated faulting between meters 300 and 600 . In this general area, near-surface $V_{\mathrm{P}}$ (particularly the $1,500 \mathrm{~m} / \mathrm{s}$ contour) is relatively shallow from about meters 0 to 250 , suggesting groundwater is higher in the section northeast of the fault zone. However, $V_{\mathrm{S}}$, which is sensitive to shearing, is relatively low in this zone of apparent faulting. Lateral variations in $V_{\mathrm{P}} / V_{\mathrm{S}}$ and Poisson's ratio values, combined with disrupted reflectors and diffractions highlight an apparent fault zone that we label fault zone $\mathrm{Z} 2$, which extends from about meters 300 to 600 of the seismic profile. However, we note that there also appears to be extended, less-intense faulting near meter 125 and between meters 600 and 1,150 of the seismic profile. Along this extended zone, we observe vertical offsets of small blocks of reflectors that have variable dips and associated diffractions.

We interpret a third zone of concentrated faulting (Z3) between meters 1,300 and 1,575, with the most intense deformation between meters 1,350 and 1,550 (fig. 9). This zone is characterized by vertically offset strata with opposing dips across the apparent fault zone (fig. 9). The zone is also highly diffractive on the reflection image. $V_{\mathrm{p}}$ (fig. 5) and $V_{\mathrm{S}}$ (fig. 6) are laterally variable across this zone, especially below about $50 \mathrm{~m}$ depth. $V_{\mathrm{P}} / V_{\mathrm{S}}$ ratios (fig. 7) and Poisson's ratio values (fig. 8) are also highly variable across this zone, and there are small variations in the depth of the $1,500 \mathrm{~m} / \mathrm{s}$ velocity contour (fig. $5 B$ ). There appears to be extended (but less dense) faulting to the southwest of this zone between about meters 1,650 and 2,000, where similar anomalies are observed on all seismic images, especially on the reflection image (fig. 9).

Interpreted faulting is most apparent in the deeper $(>25$ m) parts of the subsurface, which may not affect shallow groundwater flow from the Coachella Canal. However, from the reflection image, it is apparent the some of these faults also extend to the near surface and likely would affect groundwater flow across the Dos Palmas Preserve area.

\section{Summary}

Along our Dos Palmas Preserve seismic profile, we developed seismic reflection images and models of $V_{\mathrm{P}}, V_{\mathrm{S}}$, $V_{\mathrm{P}} / V_{\mathrm{S}}$ ratios, and Poisson's ratios, all of which can be effective in subsurface mapping of groundwater and faults. Unconsolidated, unsaturated sediments appear to vary from about 13 to $30 \mathrm{~m}$ thick (not including thin perched aquifers) along most parts of the seismic profile. Below about $13-30 \mathrm{~m}$ depth, strata appear to be more compacted, tilted, folded, and faulted, and we interpret the base of Lake Cahuilla sediments to form the top of a main thick aquifer. The $1,500 \mathrm{~m} / \mathrm{s} V_{\mathrm{P}}$ contour and strong reflectors indicate that the depth to the top of this aquifer varies laterally along the seismic profile, with significant vertical offsets (as much as about $15 \mathrm{~m}$ ) across fault zones near the northeast and southwest ends of the profile. There also appear to be smaller vertical offsets ( $\sim 3$ to $5 \mathrm{~m}$ ) in the top of the aquifer across the central part of the seismic profile.

Although from multiple seismic observations there appears to be substantial faulting along much of the Dos Palmas Preserve seismic profile, we suggest that there are at least three concentrated fault zones. One of these concentrated zones (Z1) coincides with vertical uplift between the Hidden Spring fault and a northward projection of the Powerline fault. Another zone of concentrated faulting (Z2) coincides with vertical uplift of strata (up to the northeast) near the eastern end of Dos Palmas Preserve, and the third zone (Z3) of concentrated faulting is near the center of the seismic profile. There appears to be a relatively small amount of vertical uplift within the $\mathrm{Z} 3$ zone of faulting. Faults that approach the surface in each of these zones of faulting, as well as less concentrated faulting elsewhere along the seismic profile, likely affect the flow of groundwater within the main aquifer(s) in the Dos Palmas Preserve area. Some of the faults appear to extend to the near surface and may affect the distribution of shallow, perched aquifers and their ability to provide water to various parts of Dos Palmas Preserve. 


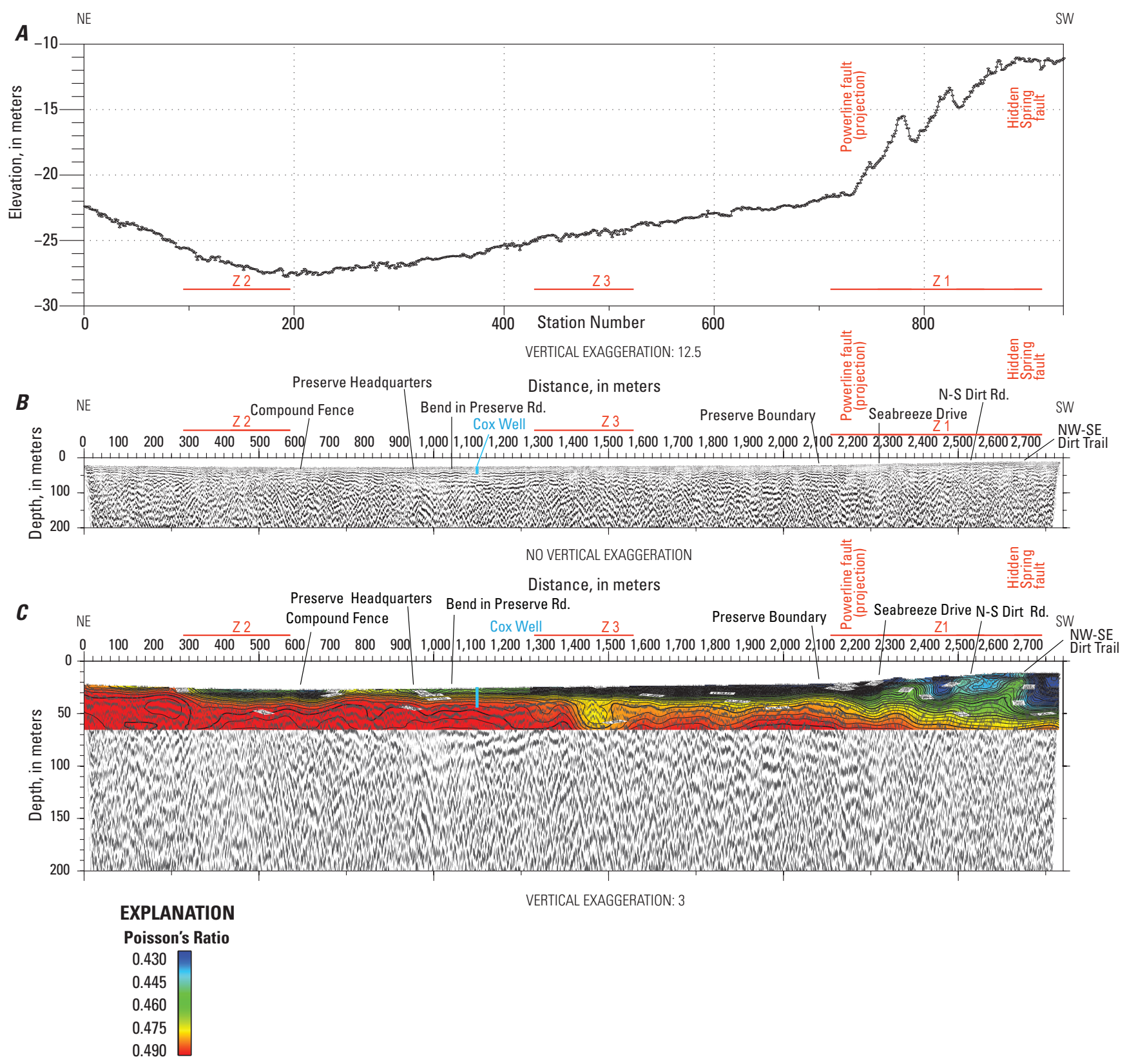

Figure 15. Comparison plots of topography, seismic reflection, and Poisson's ratio along the Dos Palmas Preserve seismic profile; land surface is approximately at top of the reflection images. Horizontal red lines labeled Z1, Z2, and Z3 show interpreted fault zones. $A$, Topography along the seismic profile. $B$, Seismic reflection stack from figure $9 B$, plotted without vertical exaggeration. Vertical blue line shows the nearest projection of the Cox well onto the seismic profile. $C$, Seismic reflection stack from figure $9 C$ with the Poisson's ratio model from figure 8 superimposed. Both are plotted with $3 x$ vertical exaggeration. Near the Cox well, a Poisson's ratio of about 0.4875 correlates with depth to the top of the first main aquifer, based on projections by Shatz and Putty (written commun., 2009). 


\section{Data Availability}

The data used in this study were published in a USGS data release (Chan and others, 2018), which is available online at https://doi.org/10.5066/P9WQJ5EH.

\section{References Cited}

Babcock, E.A., 1974, Geology of the northeast margin of the Salton Trough, Salton Sea, California: Geological Society of America Bulletin, v. 85, p. 321-332.

Bowles, J.E., 1982, Foundation analysis and design: London, McGraw-Hill, 816 p.

Bredehoeft, J.D., Belitz, K., and Sharp-Hansen, S., 1992, The hydrodynamics of the Big Horn basin-A study of the role of faults: The American Association of Petroleum Geologists Bulletin, v. 76, p. 530-546.

Carmichael, R.S., 1989, Practical Handbook of Physical Properties of Rocks and Minerals: Boca Raton, Ann Arbor, Boston, CRC Press, 741 p.

Catchings, R.D., Borchers, J.W., Goldman, M.R., Gandhok, G., Ponce, D.A., and Steedman, C.E., 2006, Subsurface structure of the East Bay plain ground-water basin-San Francisco Bay to the Hayward Fault, Alameda County, California: U.S. Geological Survey Open-File Report 2006-1084, 61 p., https://pubs.usgs.gov/of/2006/1084/.

Catchings, R.D., Cox, B.F., Goldman, M.R., Gandhok, G., Rymer, M.J., Dingler, J., Martin, P., Christensen, A., and Horta, E., 2000, Subsurface structure and seismic velocities as determined from high-resolution seismic imaging in the Victorville, California area-Implications for water resources and earthquake hazards: U.S. Geological Survey Open-File Report 00-123, 70 p.

Catchings, R.D., Gandhok, G., Goldman, M.R., Horta, E., Rymer, M.J., Martin, P., and Christensen, A., 1999a, Subsurface, high-resolution, seismic images from Cherry Valley, San Bernardino County, California-Implications for water resources and earthquake hazards: U.S. Geological Survey Open-File Report 99-26, 57 p.

Catchings, R.D., Gandhok, G., Goldman, M.R., and Okaya, D., 2001, Seismic images and fault relations of the Santa Monica Thrust Fault, West Los Angeles, California: U.S. Geological Survey Open-File Report 01-111, 34 p., https://pubs.usgs.gov/of/2001/0111/.
Catchings, R.D., Gandhok, G., Goldman, M.R., Okaya, D., Rymer, M.J., and Bawden, G.W., 2008, Near-surface location, geometry, and velocities of the Santa Monica fault zone, Los Angeles, California: Bulletin of the Seismological Society of America, v. 98, p. 124-138.

Catchings, R.D., Goldman, M.R., and Gandhok, G., 2007, Structure and velocities of the northeastern Santa Cruz Mountains and the western Santa Clara Valley, California from the SCSI-LR seismic survey: U.S. Geological Survey Open-File Report 2007-1039, 70 p.

Catchings, R.D., Goldman, M.R., Gandhok, G., Horta, E., Rymer, M.J., Martin, P., and Christensen, A., 1999b, Structure, velocities, and faulting relationships beneath San Gorgonio Pass, California-Implications for water resources and earthquake hazards: U.S. Geological Survey Open-File Report 99-568, 53 p.

Catchings, R.D., Goldman, M.R., Lee, W.H.K., Rymer, M.J., and Ponti, D.J., 1998, Faulting apparently related to the 1994 Northridge, California, earthquake and possible coseismic origin of surface cracks in Potrero Canyon, Los Angeles County, California: Bulletin of the Seismological Society of America, v. 88, p. 1379-1391.

Catchings, R.D., and Lee, W.H.K., 1996, Shallow velocity structure and Poisson's ratio at the Tarzana, California strong-motion accelerometer site: Bulletin of the Seismological Society of America, v. 86, p. 1704-1713.

Catchings, R.D., Rymer, M.J., Goldman, M.R., and Gandhok, G., 2009, San Andreas Fault geometry at Desert Hot Springs, California, and its effects on earthquake hazards and groundwater: Bulletin of the Seismological Society of America, v. 99, p. 2190-2207, https://doi.org/10.1785/ 0120080117.

Catchings, R.D., Rymer, M.J., Goldman, M.R., Gandhok, G., and Bawden, G.W., 2010, Reply to "Comment on 'Nearsurface location, geometry, and velocities of the Santa Monica Fault zone, Los Angeles, California' by R. D. Catchings, G. Gandhok, M. R. Goldman, D. Okaya, M. J. Rymer, and G. W. Bawden" by T. L. Pratt and J. F. Dolan: Bulletin of the Seismological Society of America, v. 100, p. $2338-2347$.

Catchings, R.D., Rymer, M.J., Goldman, M.R., Prentice, C.S., and Sickler, R.R., 2013, Fine-scale delineation of the location of and relative ground shaking within the San Andreas Fault zone at San Andreas Lake, San Mateo County, California: U.S. Geological Survey Open-File Report 2013-1041, 53 p., https://pubs.usgs.gov/of/2013/1041/. 
Catchings, R.D., Rymer, M.J., Goldman, M.R., Sickler, R.R., and Criley, C.J., 2014, A method and example of seismically imaging near-surface fault zones in geologically complex areas using Vp, Vs, and their ratios: Bulletin of the Seismological Society of America, v. 104, p. 1989-2006, https://doi.org/10.1785/0120130294.

Chan, J.H., Catchings, R.D., Goldman, M.R., Criley, C.J., and Sickler, R.R., 2018, 2015 high resolution seismic acquisition at Dos Palmas Preserve, Mecca, California: U.S. Geological Survey data release, https://doi.org/10.5066/ P9WQJ5EH.

Christensen, A.H., Siade, A.J., Martin, P., Langenheim, V.E., Catchings, R.D., and Burgess, M.K., 2015, Feasibility and potential effects of the proposed Amargosa Creek recharge project, Palmdale, California: U.S. Geological Survey Scientific Investigations Report 2015-5054, 48 p., https://doi.org/10.3133/sir20155054.

Gandhok, G., Catchings, R.D., Goldman, M.R., Horta, E., Rymer, M.J., Christensen, A., and Martin, P., 1999, Highresolution seismic reflection/refraction imaging from I-10 to Cherry Blvd., Cherry Valley, Riverside County, CaliforniaImplications for water resources and earthquake hazards: U.S. Geological Survey Open-File Report 99-320, 56 p.

Garambois, S., Senechal, P., and Perroud, H., 2002, On the use of combined geophysical methods to assess water content and water conductivity of near-surface formations: Journal of Hydrology (Amsterdam), v. 259, p. 32-48.

Green, A., Lanz, E., and Maurer, H., 1999, A template for geophysical investigations of small landfills: The Leading Edge, v. 18, p. 248-254, https://doi.org/10.1190/1.1438264.

Grelle, G., and Guadagno, F.M., 2009, Seismic refraction methodology for groundwater level determination- "Water seismic index": Journal of Applied Geophysics, v. 68, p. 301-320.

Haeni, F.P., 1986, Application of seismic-refraction techniques to hydrologic studies: U.S. Geological Survey Open-File Report 84-0746, 144 p.

Hayashi, K., 2008, Development of surface-wave methods and its application to site investigations: Kyoto, Japan, Kyoto University, Ph.D. dissertation, 315 p.

Hayashi, K., and Suzuki, H., 2004, CMP cross-correlation analysis of multi-channel surface-wave data: Exploration Geophysics, v. 35, p. 7-13.

Hibbs, B.J., Kelliher, M., and Erdelyi, N., 2011, Use of environmental isotopes to determine impacts on wetlands due to lining of irrigation canals, Salton Sea area, California: Proceedings of the World Environmental and Water Resources Congress 2011, p. 1064-1074.
Hole, J.A., 1992, Nonlinear high-resolution three-dimensional seismic traveltime tomography: Journal of Geophysical Research, v. 97, B5, p. 6553-6562.

Nur, A., 1982, Stanford Rock Physics Progress Report, January 1982 v. 13: Stanford, California, Stanford University, $121 \mathrm{p}$.

Nur, A., and Simmons, G., 1969, The effect of saturation on velocity in low porosity rocks: Earth and Planetary Science Letters, v. 7, p. 183-193.

Pasquet, S., Bodet, L., Dhemaied, A., Mouhri, A., Vitale, Q., Rejiba, F., Flipo, N., and Guerin, R., 2015, Detecting different water table levels in a shallow aquifer with combined $\mathrm{P}$-, surface-, and $\mathrm{SH}$-wave surveys - Insights from $\mathrm{Vp} / \mathrm{Vs}$ or Poisson's ratios: Journal of Applied Geophysics, v. 113, p. 38-50, https://doi.org/10.1016/j.jappgeo.2014.12.005.

Park, C.B., Miller, R.D., and Xia, J., 1999, Multichannel analysis of surface waves: Geophysics, v. 64, p. 800-808.

Philibosian, B., Fumal, T., and Weldon, R., 2011, San Andreas Fault earthquake chronology and Lake Cahuilla history at Coachella, California: Bulletin of the Seismological Society of America, v. 101, p. 13-38, https://doi.org/10.1785/ 0120100050 .

Rosa, C.M., Catchings, R.D., Rymer, M.J., Grove, K., and Goldman, M.R., 2016, Structure of the 1906 near-surface rupture zone of the San Andreas Fault, San Francisco Peninsula segment, near Woodside, California: U.S. Geological Survey Open-File Report 2016-1063, 35 p., https://doi.org/10.3133/ofr20161063.

Salem, H.S., 2000, Poisson's ratio and the porosity of surface soils and shallow sediments, determined from seismic compressional and shear wave velocities: Geotechnique, v. 50, p. 461-463.

Stumpel, H., Kahler, S., Meissner, R., and Milkereit, B., 1984, The use of seismic shear waves and compressional waves for lithological problems of shallow sediments: Geophysical Prospecting, v. 32, p. 662-675.

Turesson, A., 2007, A comparison of methods for the analysis of compressional, shear, and surface wave seismic data, and determination of the shear modulus: Journal of Applied Geophysics, v. 61, p. 83-91.

U.S. Geological Survey and California Geological Survey, 2006, Quaternary fault and fold database of the United States: U.S. Geological Survey database, accessed August 18, 2018, at https://earthquakew.usgs.gov/hazards/ qfaults/.

Uyanik, O., 2011, The porosity of saturated shallow sediments from seismic compressional and shear wave velocities: Journal of Applied Geophysics, v. 73, p. 16-24. 
Wallace, R.E., and Morris, H.T., 1986, Characteristics of faults and shear zones in deep mines: Pure and Applied Geophysics, v. 124, p. 107-125.

Zhu, F., Gibson, R.L., Jr., Watkins, J.S., and Yuh, S.H., 2000, Distinguishing water saturation changes from porosity or clay content changes using multicomponent seismic data: Gulf Coast Association of Geological Societies Transactions, L, p. 249-258.
Menlo Park Publishing Service Center, California Manuscript approved for publication November 19, 2019 Edited by Regan Austin

Layout and design by Kimber Petersen 
